\title{
Characteristic changes in malt, wort and beer produced from different Nigerian rice varieties as influenced by varying malting conditions
}

\author{
Chigozie E Ofoedu ${ }^{\text {Corresp., } 1}$, Chibugo Q Akosim ${ }^{1}$, Jude O Iwouno ${ }^{1}$, Chioma D Obi ${ }^{2}$, Ivan Shorstkii ${ }^{3}$, Charles \\ Odilichukwu R Okpala ${ }^{\text {Corresp. } 4}$ \\ ${ }^{1}$ Department of Food Science and Technology, School of Engineering and Engineering Technology, Federal University of Technology, Owerri, Owerri, Imo, \\ Nigeria \\ 2 Department of Food Science and Technology, Nnamdi Azikiwe University, Awka, Anambra, Nigeria \\ 3 Department of Technological Equipment and Life-Support Systems, Kuban State Technological University, Krasnodar, Russian Federation \\ 4 Department of Functional Food Products Development, Faculty of Biotechnology and Food Science, Wroclaw University of Environmental and Life \\ Sciences, Wroclaw, Poland \\ Corresponding Authors: Chigozie E Ofoedu, Charles Odilichukwu R Okpala \\ Email address: chigozie.ofoedu@futo.edu.ng, charlesokpala@gmail.com
}

Gluten-free beer could be produced with rice, although the latter would primarily serve as adjunct in combination with barley malt in today's brewing. But, the recent growing realisation on the potentials and applications of rice malt for brewing an all-rice malt beer through varying malting conditions cannot be overlooked. In this study, therefore, the characteristic changes in malt, wort and beer from different Nigerian rice varieties (FARO 44, FARO 57, NERICA 7) as influenced by varying malting conditions (steeping duration [18, 24 and $30 \mathrm{~h}$ ], germination periods [2, 3 and 4 days] and kilning temperatures [50 and $\left.55^{\circ} \mathrm{C}\right]$ ), were investigated. Rice (grain) samples were examined by thousand kernel weight (TKW), germinative energy (GE), germinative capacity (GC), and degree of steeping (DoS). To ensure that rice wort/beer with unique beer style and enhanced attributes, comparable to barley wort/beer is produced, malting conditions that produced rice malts with peak diastatic power (DP), cold water extract (CWE) and hot water extract (HWE) were selected. Peak DP, CWE and HWE were obtained at FARO 44 [18h steeping, 3days germination, $55^{\circ} \mathrm{C}$ kilning $\left(\mathrm{S}_{18} \mathrm{G}_{3} \mathrm{~K}_{55^{\circ}}\right)$ ], FARO 57 [30h steeping, 2days germination, $50^{\circ} \mathrm{C}$ kilning $\left(\mathrm{S}_{30} \mathrm{G}_{2} \mathrm{~K}_{50^{\circ}}\right)$ ] and NERICA 7 [24h steeping, 3days germination, $55^{\circ} \mathrm{C}$ kilning $\left(\mathrm{S}_{24} \mathrm{G}_{3} \mathrm{~K}_{55^{\circ}}\right)$ ]. Selected malts were further tested for moisture content (MC), total nitrogen (TN), malt yield (MY), and malting loss (ML), and subsequently progressed to wort and beer production. Wort's $\mathrm{pH}$, total soluble nitrogen (TSN), brix, kolbach index (KI), free amino nitrogen (FAN), dextrose equivalent $(D E)$, original extract $(\mathrm{OE})$, and sugar profile were determined, as well as beer's $\mathrm{pH}$, colour, apparent extract ( $\mathrm{AE})$, alcohol by volume (\%ABV), turbidity, and sensory attributes. Rice grain varied significantly $(p<0.05)$ in TKW, GE, GC, and DoS across 
varieties. Despite wort's $\mathrm{pH}, \mathrm{TSN}, \mathrm{DE}, \mathrm{OE}$ as well as beer $\mathrm{pH}$, colour, $\mathrm{AE}$, and turbidity resembling ( $p>0.05$ ) across varieties, wort's brix, KI, FAN, sugar profile as well as beer's $\% A B V$, differed significantly $(p<0.05)$. Sensory attributes of appearance, colour, mouthfeel, and overall acceptability in beer differed noticeably $(p<0.05)$, except for aroma and taste $(p>0.05)$. Overall, the rice beer, though very slightly hazy, represented a pale yellow light lager, which is indicative of its peculiar beer style. Besides increased DP and enhanced hydrolysis, varying malting conditions of current study could serve as a pathway of reducing the cost of exogenous (commercial) enzymes or barley malt imports, together with decreasing barley's dependency for brewing in the tropics. 
1 To be accepted at: PeerJ

\section{Characteristic changes in malt, wort and beer produced 3 from different Nigerian rice varieties as influenced by 4 varying malting conditions}

Chigozie E. Ofoedua ${ }^{*}$, Chibugo Q. Akosimª, Jude O. Iwouno ${ }^{a}$, Chioma D. Obib§, Ivan Shorstkiic and Charles Odilichukwu R. Okpala ${ }^{\mathrm{d}^{*}}$

aDepartment of Food Science and Technology, School of Engineering and Engineering Technology, Federal University of Technology, Owerri, Imo State, Nigeria.

10 bDepartment of Food Science and Technology, Nnamdi Azikiwe University, Awka,

11 Anambra State, Nigeria.

12 'Department of Technological Equipment and Life-Support Systems, Kuban State 13 Technological University, Krasnodar, Russian Federation.

14 dDepartment of Functional Food Products Development, Faculty of Biotechnology and

15 Food Science, Wroclaw University of Environmental and Life Sciences, 50-375

16 Wroclaw, Poland.

$\S$ This current work is dedicated to late Chioma D. Obi (Mrs.), who passed away on June $1,2020$.

*Corresponding authors: chigozie.ofoedu@futo.edu.ng, (CE Ofoedu); charlesokpala@gmail.com, (COR Okpala)

Running title: Changes in rice malt, wort and beer properties 


\section{Abstract}

Gluten-free beer could be produced with rice, although the latter would primarily serve as an adjunct in combination with barley malt in today's brewing. But, the recent growing realisation on the potentials and applications of rice malt for brewing an all-rice malt beer through varying malting conditions cannot be overlooked. In this study, therefore, the characteristic changes in malt, wort and beer from different Nigerian rice varieties (FARO 44, FARO 57, NERICA 7) as influenced by varying malting conditions (steeping duration [18, 24 and $30 \mathrm{~h}$ ], germination periods [2, 3 and 4 days] and kilning temperatures [50 and $\left.55^{\circ} \mathrm{C}\right]$ ), were investigated. Rice (grain) samples were examined by thousand kernel weight (TKW), germinative energy (GE), germinative capacity (GC), and degree of steeping (DoS). To ensure that rice wort/beer of unique beer style and enhanced attributes comparable to barley wort/beer is produced, only malting conditions that delivered rice malts with peak diastatic power (DP), cold water extract (CWE) and hot water extract (HWE) were selected. Peak DP, CWE and HWE were obtained at FARO 44 [18h steeping, 3days germination, $55^{\circ} \mathrm{C}$ kilning $\left(\mathrm{S}_{18} \mathrm{G}_{3} \mathrm{~K}_{55^{\circ}}\right)$ ], FARO 57 [30h steeping, 2days germination, $50^{\circ} \mathrm{C}$ kilning $\left(\mathrm{S}_{30} \mathrm{G}_{2} \mathrm{~K}_{50^{\circ}}\right)$ ] and NERICA 7 [24h steeping, 3days germination, $55^{\circ} \mathrm{C}$ kilning $\left.\left(\mathrm{S}_{24} \mathrm{G}_{3} \mathrm{~K}_{55^{\circ}}\right)\right]$. Selected malts were further tested for moisture content (MC), total nitrogen (TN), malt yield (MY), and malting loss (ML), which subsequently progressed to wort and beer production. Wort's $\mathrm{pH}$, total soluble nitrogen (TSN), brix, kolbach index (KI), free amino nitrogen (FAN), dextrose equivalent (DE), original extract (OE), and sugar profile were determined, as well as beer's $\mathrm{pH}$, colour, apparent extract (AE), alcohol by volume (\%ABV), turbidity, and sensory attributes. Rice grain varied significantly $(\mathrm{p}<0.05)$ in TKW, GE, GC, and DoS across varieties. Despite wort's pH, TSN, DE, OE as well as beer $\mathrm{pH}$, colour, $\mathrm{AE}$, and turbidity resembling $(\mathrm{p}>0.05)$ across varieties, wort's brix, KI, FAN, sugar profile as well as beer's \%ABV, differed significantly $(p<0.05)$. Sensory attributes of appearance, colour, mouthfeel, and overall acceptability in beer differed noticeably $(\mathrm{p}<0.05)$, except for aroma and taste ( $p>0.05)$. Overall, the rice beer, though very slightly hazy, represented a pale yellow light lager, which is indicative of its peculiar beer style. In addition to benefits of increased DP and enhanced hydrolysis, varying malting conditions of the current study could play a vital role in reducing the cost of exogenous (commercial) enzymes or barley malt imports, together with decreasing barley's dependency for brewing in the tropics. Keywords: malting conditions; rice malt; rice beer; rice wort; mashing process 


\section{Introduction}

64 The global production of rice (Oryza sativa), to meet up with the increasing consumer

65 66 demand, is projected to potentially double by 2050 (USDA-ERS, 2019; OECD/FAO, 2019). In Africa, Nigeria has led the rice production (Daoui, 2018) where for instance, the 2018 rice paddy production recorded 6.81 million tonnes (World Data Atlas, Accessed 08 June 2020). The recent curb of rice importation was targeted to facilitate increased local production (Russon, 2019). However, Nigeria increasingly imported barley malt until the 1988 ban (Koleoso \& Olatunji, 1992), after which the focus on indigenous breweries intensified pushing the locally produced and commercially viable cereals like maize, rice, and sorghum, to thrive. Besides rice, barley is another global cereal that breweries utilize (Contreras-Jimenez et al., 2018, Daneri-Castro, Svensson \& Roberts, 2016). Non-temperate countries are largely limited to produce barley in commercial quantities and have no alternative but to supplement by the importation of (either malted or unmalted) grains for their breweries. Prior to the 1988 Nigeria barley malt importation ban, however, various pilot plant and commercial tests had established locally cultivated sorghum malt or grit as brewing candidates compared with existing barley malt brands (Koleoso \& Olatunji, 1992). Resembling those of sorghum, malted maize brewing properties could potentially replace the barley malt (Okafor \& Aniche, 1980). By assessing malting and brewing potentials, Okafor and Iwouno (1991) reported Nigerian rice varieties as a promising substitute for barley in beer production. Odibo, Nwankwo, and Agu (2002) reported fermentable extracts from locally cultivated sorghum to keep for a longer time until required in the brewing process. Whilst Ogbeide (2011) showed sorghum as an adjunct to malted barley in the wort production/brewing process, Iwouno and Ojukwu (2012) showed the malting quality potential of a Nigerian locally cultivated yellow maize variety. Recently, Ofoedu, Osuji, and Ojukwu (2019) reported that the sugar profile of local rice product/derivate (syrup) resembled that of barley wort.

Malting, within the brewing process, is employed particularly to prepare the brewing raw material. The next step that subsequently follows is the mashing and wort fermentation. It is important to reiterate that the malting process involves steeping, germination, and kilning. This process is very crucial in beer production because it helps to develop/prepare the inactive hydrolytic enzymes present in the raw grain (Dewar, Taylor \& Berjak, 1997). Steeping enhances grain softening, increases water availability, and stimulates germination (Sripriya, Anthony \& 
94 Chandra, 1997). Germination facilitates the production of hydrolytic enzymes which aids in 95 grain transformation (Osuji, Ofoedu \& Ojukwu, 2019). Kilning reduces the grain moisture, stops 96 germination (arrest enzyme action), and enhances the production of malt color via Maillard 97 reaction (Skendi \& Papageorgiou, 2018). Mashing, however, facilitates the enzymatic 98 degradation of polysaccharides that are present (in the malt) to simple sugars, which eventually 99 converts to alcohol in the fermentation step of the beer manufacturing (Gupta, Abu-Ghannam \& 100 Gallaghar, 2010). Moreover, it has been understood that the low protein and fat content of rice 101 have the potential to assure a slightly higher starch content of 80 to $90 \%$ (Wani et al., 2012; 102 Omar et al., 2016; Othman \& Omar, 2017) compared to barley starch content of approximately $10370 \%$ (Asare et al., 2011; Zhu, 2017). This aspect of rice might suggest a higher extract yield 104 (Narziss \& Back, 2012), though with different starch structure, and composition in amylose and amylopectin, as well as a lower amylolytic activity than barley (Cela et al., 2020). Therefore,

106 there is a need to optimise the malting and mashing conditions of rice. Moreover, rice has been

107 reported to yield incomplete saccharified mash (wort) (Teeravivattanakit et al., 2017; Roberto et 108 al., 2020) which could due to its insufficient inherent starch-degrading enzymes (low diastatic power) and high gelatinization temperature (Cela et al., 2020), owed to the nature of rice starch.

Applying such processing methods as malting on rice can enhance the degradation

111 (depolymerization) of its high molecular weight constituents (starch and proteins) to achieve

112 lower molecular weight constituents (sugars and amino acids), which could eventually influence

113 its composition and functionality during processing (Shumin et al., 2014). This opinion appears

114 to concur with the findings of previous workers (Mayer et al., 2014; Usansa et al., 2011)

115 wherein, despite the lower diastatic power of rice compared to barley, rice can serve as a raw

116 material candidate for brewing given its higher limit-dextrinase content compared to barley that

117 elevates the complete saccharification of rice wort, provided the malting conditions are

118 optimised. In addition, the high fiber content of rice assures an enhanced lautering process,

119 attributable to its filtering capacity (Kongkaew, Usansa \& Wanapu, 2012). The sufficient

120 (structural) protein degradation either prior to or simultaneously with starch saccharification,

121 according to Narziss and Back (2012), can expose the grain cell wall structure, thus enhancing

122 the easy breakdown of its endosperm (Shumin et al., 2014; Kohorn, 2000). As the protein

123 degradation appears more challenging in the malted rice compared to barley, the endogenous

124 enzyme in the rice malt would facilitate the breakdown of rice constituents in vivo and improve 
125 the extract yield in the wort production. During the malting process, additionally, the rice would 126 attain a higher alpha-amylase production (Ayernor \& Hammon, 2000) together with a suitable

127 beta-amylase activity (Cela et al., 2020). Besides starch and protein degradation of rice, the

128 actions of malting conditions enhance enzyme production, which aids in vivo hydrolysis of

129 endosperm in the rice kernel during germination and in vitro hydrolysis during mashing

130 (Hassani, Zarnkow \& Becker, 2013; Garzon, Torres \& Drago, 2016). Varying the malting

131 conditions, so as to ascertain the situation that would bring about rice malts with potentially

132 higher diastatic power, and fermentable extracts appears a promising remedy to the brewing

133 challenges associated with rice.

134 Nigeria's local rice varieties, having evolved over the years with improved qualities like

135 (longer) grain length, improved colour/cooking quality, etc, continues to compete with foreign

136 ones, thrives increasingly, and spreads its distribution/reputation to the West African sub-region.

137 Besides the increased interest to find local/indigenous raw material(s) to supplement barley in

138 brewing, to help reduce (barley) imports, increase (local/indigenous) rice production (Index

139 Mundi, 2020), Nigeria's quest to attain self-sufficiency (in rice production) is not far-fetched, as

140 have been described elsewhere (Ofoedu et al., 2020). Placing the greater emphasis on

141 such underutilized indigenous rice varieties, particularly those perceived as undesirable due

142 to widely accepted factors such as poor cooking quality (soft and sticky grains), poor physical

143 attributes (poor colour, short-grain length, etc.), and poor consumer acceptability,

144 therefore, makes (rice) product quality diversification should be very fitting. The growing

145 realisation of researchers, (rice) processors, and local breweries about the potentials as well as

146 the diverse applications of these (underutilized indigenous) rice varieties, have recently

147 facilitated (rice) product diversification, to actualise promising products like syrups (Ofoedu et

148 al., 2020), gluten-free beers (Cela et al., 2020), flours, and malts (Osuji, Ofoedu \& Ojukwu,

149 2019). Additionally, even though rice grits have served as adjuncts in brewing, the use of rice

150 malt as a specialty ingredient or base malt in the brewing industry, for instance, an all-rice malt

151 beer (gluten-free rice beer) (Marconi, Sileoni, Ceccaroni \& Perretti, 2017) should be very

152 promising. Additionally, the malted rice specifically harnessed from locally produced indigenous

153 rice varieties in Nigeria appears not fully explored, particularly as a principal raw material or

154 substrate for brewing. In the context of the (above-mentioned) discourse, therefore, this current

155 work was specifically purposed to determine the characteristic changes in malt, wort, and beer

Peer] reviewing PDF | (2020:10:54302:1:1:NEW 16 Jan 2021) 
156 produced from different (Nigerian) rice varieties as influenced by varying malting conditions.

157 The indigenous rice varieties used for this study are locally available and in commercial

158 quantities.

\section{Materials and Methods}

160 Schematic overview of experimental program

161 The schematic overview of experimental study, showing the key/major stages from the

162 procurement of rice samples through malting, wort production and beer production to laboratory

163 analyses, is shown in Figure 1. Specifically, this current work was designed to determine the

164 characteristic changes in malt, wort and beer produced from different (Nigerian) rice varieties as

165 influenced by varying malting conditions. This was done by investigating the impact of varying

166 the experimental variables (steeping durations [18 h, $24 \mathrm{~h}$ and $30 \mathrm{~h}]$, germination periods [2, 3

167 and 4 days], and kilning temperatures $\left[50^{\circ} \mathrm{C}\right.$ and $\left.55^{\circ} \mathrm{C}\right]$ ), on rice malt quality with reference to

168 dependent variables (cold water extract [CWE], hot water extract [HWE], and diastatic power

169 [DP]). Consequently, the rice malts with higher dependent variables (CWE, HWE, and DP)

170 progressed to mashing and brewing. By comparing rice varieties, however, the effect of malting

171 conditions on rice wort and beer, as exerted by the selected rice malts were determined using

172 some key parameters/indices. Duplicate determinations were carried out by analysing aliquot

173 samples from the sample population (rice malt, rice wort, and rice beer) across the rice varieties.

174 Procurement of chemicals, enzymes and rice grains

175 Procured from certified sources, all chemicals and reagents (i.e., Copper (II) sulphate

176 pentahydrate $\left(\mathrm{CuSO}_{4} \cdot 5 \mathrm{H}_{2} \mathrm{O}\right)$, Potassium sodium tartrate tetrahydrate $\left(\mathrm{KNaC}_{4} \mathrm{H}_{4} \mathrm{O}_{6} \cdot 4 \mathrm{H}_{2} \mathrm{O}\right)$,

177 Calcium hydroxide $\left(\mathrm{Ca}(\mathrm{OH})_{2}\right)$, hydrochloric acid $(\mathrm{HCl})$, boric acid $\left(\mathrm{H}_{3} \mathrm{BO}_{3}\right)$, potassium sulphate

$178\left(\mathrm{~K}_{2} \mathrm{SO}_{4}\right)$, sulfuric acid $\left(\mathrm{H}_{2} \mathrm{SO}_{4}\right)$, Trioxonitrate $(\mathrm{V})$ acid $\left(\mathrm{HNO}_{3}\right)$, sodium metabisulphite

$179\left(\mathrm{Na}_{2} \mathrm{~S}_{2} \mathrm{O}_{5}\right)$, Sodium hydroxide $(\mathrm{NaOH})$, Ammonium hydroxide $\left(\mathrm{NH}_{4} \mathrm{OH}\right)$, Ninhydrin, Methylene

180 blue indicator, Phenolphthalein indicator, Fehling's solution, Anhydrous D-glucose) were of

181 analytical grade standard.

182 Commercial exogenous microbial enzymes (namely: $\alpha$-amylase $[25 \mathrm{U} / \mathrm{mL}]$ and $\beta$ -

183 amylase $[15 \mathrm{U} / \mathrm{mL}]$ ) were procured from Nigerian breweries PLC (Awo-Omamma, Imo State,

184 Nigeria). Protease (microbial) enzyme having $10 \mathrm{U} / \mathrm{mL}$ enzyme activity and isomerised hops

185 used were procured from Department of Applied Microbiology and Brewing, Enugu State

186 University of Science and Technology, Enugu State, Nigeria. Yeast strain (Saccharomyces 
187 pastorianus) was procured from the Nigerian Breweries PLC (Ama, Enugu State, Nigeria). 188 Improved rice grains (FARO 44, FARO 57 and NERICA 7) were purchased from

189 National Cereals Research Institute, Amakama, Olokoro Umuahia, Abia State, Nigeria.

190 Rice grain analysis

191 Evaluation of rice grain

192 Grain quality analyses (such as thousand kernel weight, germinative energy, germinative 193 capacity, degree of steeping, etc.) are important for the evaluation of suitability of rice variety for 194 malting and brewing (Marconi et al., 2017). In this current work, thousand kernel weight, 195 germinative energy, germinative capacity, and degree of steeping were determined.

\section{Determination of thousand kernel weight (TKW)}

TKW was determined according to the method described by Esiape (1994). Hundred

198 (100) grains of paddy rice randomly selected from the bulk were weighed using a weighing 199 balance. Each weight was multiplied by 10 to obtain the 1000 kernel weight. Determinations 200 were done in duplicate.

Determination of germinative capacity $(G C)$ and germinative energy (GE) features of good malt. For this current study, the GE and GC (presented in percent [\%]) of rice (IoB) (2007).

$$
\text { Germinative energy }(\%)=\frac{\text { Number of viable grains }}{\text { Total number of grains }} \times 100
$$

Eq. 1

$$
\text { Germinative capacity }(\%)=\% \text { Germinative energy - \% Dormancy }
$$

Eq. 2

209 Herein, dormancy is rice grain's inherent inability to germinate under optimal environmental 210 conditions expressed as; 


$$
\% \text { Dormancy }=\frac{\text { Number of unviable grains }}{\text { Total number of grains }} \times 100
$$

Eq. 3

\section{Determination of degree of steeping (DoS)}

212 DoS measures the amount of water readily absorbed by the grains. DoS expressed as percentage

213 (\%) was determined by the method described by Kunze (2005) with slight modification. One

214 hundred grams rice kernels of predetermined moisture content were soaked in a $100 \mathrm{ml}$ beaker

215 containing $50 \mathrm{ml}$ of distilled water at ambient temperature $\left(28^{\circ} \mathrm{C} \pm 2\right)$. Steeping was done

216 continuously until constant weights were attained and recorded. Soak waters were drained off the

217 grains by the use of sieves. From the increase in mass, the degree of steeping was calculated as;

$$
\begin{array}{ll}
\text { Degree of Steeping }(\%)=\frac{\mathrm{X}}{\mathrm{Wi}} \times 100 \quad \text { Eq. } 4 &
\end{array}
$$

218

219 Where $\mathrm{X}=$ Variable expressed in grams $(\mathrm{g})$, showing the relationship between $\mathrm{W}_{\mathrm{i}}, \mathrm{W}_{\mathrm{f}}$ and $\mathrm{M}_{\mathrm{C}}$;

$220 \frac{\mathrm{Wi} \times(\mathrm{D}+\mathrm{Mc})}{\mathrm{Wf}}$

$221 \mathrm{~W}_{\mathrm{i}}=$ Mass of rice grain before steeping $(\mathrm{g})$

$222 \mathrm{~W}_{\mathrm{f}}=$ Mass of rice grain after steeping $(\mathrm{g})$

$223 \mathrm{M}_{\mathrm{C}}=$ Moisture content of rice grain (\%)

$224 \mathrm{D}=$ Mass of water absorbed by rice grain $\left(\mathrm{W}_{\mathrm{f}}-\mathrm{W}_{\mathrm{i}}\right)(\mathrm{g})$

225 Malting of rice grain

226 After manual cleaning, the paddy rice of different varieties sorted to remove

227 contaminants/damaged seeds, was winnowed to remove dust. Prior to malting, the rice paddy

228 were disinfected in water containing $0.20 \%$ sodium metabisulphite. The malting process

229 followed method of Kunze (2004) with some modifications. Briefly, rice samples were steeped

230 in water at $20-25^{\circ} \mathrm{C}$ for 18,24 , and $30 \mathrm{~h}$ with alternating steep cycle of $6 \mathrm{~h}$ wet-steep period

231 and $30 \mathrm{~min}$ air rest. Grains were allowed to germinate, thereafter removed after 2, 3, and 4 days

232 and kilned in hot air oven (Genlab, England, Model M 30 C, S/N 92B060) at temperatures 
233 between $50-55^{\circ} \mathrm{C}$ for about $22-24 \mathrm{~h}$. Kilned samples were manually de-rooted by rubbing off

234 with hand, winnowed to remove the rootlets/dust and milled to produce the rice grist.

\section{Production of rice malt wort}

236 The flow diagram of rice malt wort production presented in Figure 2, which was slightly 237 modified from previous studies (Okafor \& Iwouno, 1990; Nwanekezi, Osuji \& Onyeneke, 2007; 238 Marconi et al., 2017; Ofoedu et al., 2019; Iwouno, Ofoedu, Ugwuegbulam \& Nwokoro, 2019) of 239 under modified cereal (rice) malts, involved a three-step decoction mashing process. Rice malt 240 grist $(\sim 2 \mathrm{~kg})$ was dissolved in clean filtered potable water $(8 \mathrm{~L})$ previously made to a $\mathrm{pH}$ of 11.0 241 using $\mathrm{Ca}(\mathrm{OH})_{2}$ solution. The entire mash temperature was raised to $35-40{ }^{\circ} \mathrm{C}$ to acidulate the 242 mash followed by addition of $1 \mathrm{~mL}$ of protease for proteolysis to take place, with temperature 243 maintained for $30 \mathrm{~min}$ at gentle stirring (acid rest). First decoction involved transferring one244 third of the mash to a mash kettle and heated to $70^{\circ} \mathrm{C}$. Heated mash was transferred back to the 245 remaining two-third mash, with entire temperature raised to $50-55^{\circ} \mathrm{C}$, followed by addition of $246 \alpha$-amylase $(0.8 \mathrm{~mL})$ and subsequently allowed to rest for $30 \mathrm{~min}$. In the second decoction, one247 third of the mash was further heated in the mash kettle $(3-5 \mathrm{~min})$ until temperature of $85^{\circ} \mathrm{C}$ was 248 reached, then transferred to the remaining two-third thin mash, raising the temperature to $\sim 67^{\circ} \mathrm{C}$ 249 and the mash gelatinized, which was allowed to rest for $30 \mathrm{~min}$ after addition of $\alpha$-amylase (0.8 $250 \mathrm{~mL}$ ). Following liquefaction, a third decoction involved raising temperature to $100^{\circ} \mathrm{C}$, wherein

251 boiled mash was added to the remaining mash, which moderated the entire temperature to about

$25272-75^{\circ} \mathrm{C}$. Mash rested again for $\sim 30 \mathrm{~min}$ after addition of $\beta$-amylase $(0.8 \mathrm{~mL})$ prior to 253 saccharification. To denature the enzymes prior to wort lautering, mashing-out was carried out.

254 Spent grains were sparged with $1000 \mathrm{~mL}$ of hot sparge water at $80{ }^{\circ} \mathrm{C}$ to obtain the entire wort 255 from the mashing operation, before wort was concentrated.

256

257

258

259

260

261

\section{Production of rice malt beer}

In this study, the Japanese rice lager (beer style) production process was adopted (Briess, 2020; Beeradvocate, 2020) for the production of rice malt beer, following the method described by Briggs et al. (2004) with slight modification. Briefly, rice malt wort was boiled together with hop extracts for $30 \mathrm{~min}$ and thereafter, allowed to cool. Undissolved particles were removed and the filtered wort was transferred into fermenters. Already activated yeast $(3 \mathrm{~g})$ culture 
262 (Saccharomyces pastorianus) was pitched into the fermenting vessel at $20^{\circ} \mathrm{C}$ and fermentation

263 was carried out at $10-20{ }^{\circ} \mathrm{C}$ for 8 days. Green beer was filtered and allowed to age for 21 days.

264 Matured/draft beer was siphoned into sterile bottles, pasteurized at $60^{\circ} \mathrm{C}$ for $15 \mathrm{~min}$, and

265 subsequently, analysed.

266 Rice malt analyses

267 Malt analyses are carried out in accordance with standard methods of the Institute of

268 Brewing (IoB), European Brewing Convention (EBC) and American Society of Brewing

269 Chemists (ASBC) for several purposes such as to provide data for the maltster to use for quality

270 control and to guide process adjustments, to provide a basis for product valuation, for prediction

271 of extract recovery, to indicate the potential value of the malt and whether or not a particular

272 malt is likely to give production difficulties (Briggs, 1998).

273 Determination of cold water extract (CWE)

274

CWE measures the pre-formed water-soluble substances present in rice malt (Briggs,

275 1998). CWE (presented in $\mathrm{g} / 100 \mathrm{~g}$ ) was determined using method recommended by Institute of

276 Brewing (IoB) (2007) and was calculated using equation below:

$$
\text { Cold Water Extract }(\%)=\frac{G \times 100}{3.86} \times 20
$$

Eq. 5

278 where,

$279 \mathrm{G}=$ dimensionless quantity depicting the excess degrees of gravity of the filtrate at $15.5^{\circ} \mathrm{C}$ as $280 \quad 1000$

281 i.e. $\mathrm{G}=1000(\mathrm{SG}-1)$

$282 \quad \mathrm{SG}=$ Specific gravity

283 Determination of hot water extract (HWE)

284 HWE measures the extractable materials derived from rice malt after a small scale 285 mashing process (Briggs, 1998). HWE expressed as liter degrees $/ \mathrm{kg}\left(\mathrm{L}^{\circ} / \mathrm{kg}\right)$ was determined 286 using method recommended by Institute of Brewing (IoB) (2007) and was calculated using the 287 equation below; 
Hot Water Extract $(\mathrm{L} / \mathrm{kg})=\frac{\mathrm{G} \times \mathrm{V}}{\mathrm{M}}$

Eq. 6

288

289

290 where,

$291 \mathrm{G}=$ dimensionless quantity depicting the excess degrees of gravity of the filtrate at $15.5^{\circ} \mathrm{C}$ as

2921000

293 i.e. $\mathrm{G}=1000(\mathrm{SG}-1)$

$294 \mathrm{~V}=$ Volume of wort in Litres (L)

$295 \mathrm{M}=$ Mass of rice malt in Kilogram $(\mathrm{kg})$

296 SG $=$ Specific gravity

297 Determination of diastatic power (DP)

298 DP measures the amount of enzyme in rice malt available to convert complex

299 carbohydrates/starches into fermentable sugars (Ackley, 2018). DP expressed in lintner degree

300 ( ${ }^{\circ}$ Lintner) was determined using method recommended by Institute of Brewing (IoB) (2007) and

301 was calculated using the equation below;

Diastatic Power $\left({ }^{\circ}\right.$ Lintner $)=\frac{2000-200}{\mathrm{xy}-\mathrm{xs}}$

Eq. 7

302 where:

$303 \mathrm{x}=$ Volume of rice malt extract $(\mathrm{mL})$

$304 \mathrm{y}=$ Volume of converted starch to $5 \mathrm{~mL}$ of the Fehling's solution (mL)

$305 \mathrm{~s}=$ Titre for starch blank $(\mathrm{mL})$

306 Determination of moisture content (MC) and total nitrogen (TN)

307 Rice malt with higher diastatic power (DP), cold water extract (CWE), and hot water

308 extract (HWE) were selected for wort production/brewing trial. Only these were subject to

309 determinations of moisture content (MC) presented in $\mathrm{g} / 100 \mathrm{~g}$ (wet basis) via the method

310 described in AOAC (2006), and total nitrogen (TN) presented in $\mathrm{g} / \mathrm{L}$ via the Kjeldahl method

311 (European Brewery Convention, 2006).

Peer] reviewing PDF | (2020:10:54302:1:1:NEW 16 Jan 2021) 


\section{Determination of malting loss $(M L)$}

313 Malting loss (ML) after germination was determined according to the method described by

314 Adebowale et al., (2010) by weighing the rice grains before and after malting. The weight of 100

315 grains of rice was recorded before malting and the weight of the malted grains after the rootlets

316 were removed by hand was also recorded. Malting loss was expressed as percentage (\%) on dry

317 matter basis.

Malting loss $(\%)=\frac{\text { Weight of unmalted grain }- \text { Weight of malted grain }}{\text { Weight of unmalted grain }} \times 100 \quad$ Eq. 8

\section{Determination of malt yield (MY)}

319 Malt yield (MY) after germination was determined according to the method described by

320 Adebowale et al., (2010) by weighing the rice grains before and after malting. The weight of 100

321 grains of rice was recorded before malting and the weight of the malted grains after the rootlets

322 were removed by hand was also recorded. Malt yields were expressed as percentage (\%) on dry

323 matter basis.

$$
\text { Malt yield }(\%)=\frac{\text { Weight of malted grain }}{\text { Weight of unmalted grain }} \times 100
$$

324

325

326

327

328

329

330

331

332

333

334 Noonan, 2003). TSN of rice malt wort, expressed in $\mathrm{g} / \mathrm{L}$ was determined using Kjeldhal method

335 (Institute of Brewing (IoB), 2007). 
336

337

338

339

340

341

342

343

344

345

346

347

348

349

350

351

352

353

354

355

356

357

358

359

360

361

Determination of apparent brix $\left({ }^{\circ} B x\right)$

Brix of rice malt wort was determined using a Milwaukee Digital brix Refractometer Model MA871 (Milwaukee Instruments, NC - USA) (Montañez-Soto et al., 2013), which involved refractometer standardized with distilled water at $20^{\circ} \mathrm{C}$ until brix value read zero, followed by two drops of wort sample on the lens (sensitive surface), and measurement conducted subsequently.

Determination of kolbach index (KI)

KI measures the degree/extent of protein modification/degradation, as a ratio of TSN in wort to TN in the rice malt (Bamforth, 2003; Olivier \& Colicchio, 2012). KI expressed in \%, was calculated consistent with Analytical - EBC (1998) method, using the equation below:

$$
\text { Kolbach Index }(\%)=\frac{\mathrm{TSN}}{\mathrm{TN}} \times 100
$$

Where TSN $=$ Total soluble nitrogen $(\mathrm{g} / \mathrm{L})$

$\mathrm{TN}=$ Total nitrogen $(\mathrm{g} / \mathrm{L})$

\section{Determination of free amino nitrogen (FAN)}

FAN of rice malt wort was determined by Ninhydrin method (European Brewery Convention, 1998) with slight modifications. The sample (1mL) diluted with deionised water to $100 \mathrm{~mL}$, then $2 \mathrm{~mL}$ of diluted sample mixed with $1 \mathrm{~mL}$ of colour reagent, placed in boiled water for $16 \mathrm{~min}$, allowed to cool to $20^{\circ} \mathrm{C}$. Diluted solution $(5 \mathrm{~mL})$ was added, followed by measurement of optical density at $570 \mathrm{~nm}$. Blank was determined with $2 \mathrm{~mL}$ of deionized water. Glycine standard solution was checked using $2 \mathrm{~mL}$ of glycine solution. The FAN content was calculated and expressed in $\mathrm{mg} / \mathrm{L}$.

Determination of dextrose equivalence $(D E)$

DE measures the amount of reducing sugars present in a sugar product, relative to glucose (Dziedzic \& Kearsley, 1995) determined on rice malt wort, using the Lane and Eynon Fehling's solution method as previously described (International Starch Institute, 1999). 
362

363

364

365

366

where Mass percent $\equiv$ Apparent brix value

Original Extract $(\mathrm{g} / 100 \mathrm{~g})=259-\left(\frac{259}{\mathrm{SG}}\right)$

367 Where $\mathrm{SG}=$ Specific gravity

368

369

370

371

372

373

374

375

376

377

378

379

380

381

382

383

384

385

386

387

Determination of original extract $(O E)$

$$
\text { Specific Gravity }(\mathrm{SG})=(\text { Mass percent } \times 0.004)+1
$$

\section{Determination of wort sugar profile} described in AOAC Official Method 982.14 (2006).

\section{$\underline{\text { Rice malt beer analyses }}$} was determined by EBC method 9.10.

\section{Determination of sensory attributes}

OE measures wort density compared to that of water at equal volume and temperature (ASBC, 2009). OE of rice malt wort presented in $\mathrm{g} / 100 \mathrm{~g}$ was calculated from an approximate Plato value as previously described (Kunze, 2004), calculated using equation below:

Eq. 11

The sugar profile of rice malt wort was determined using HPLC according to the method

\section{Determination of $\mathrm{pH}$, colour, apparent extract, alcohol and turbidity}

The $\mathrm{pH}$, colour, apparent extract, alcohol and turbidity was evaluated using the following Analytical-EBC methods (European Brewery Convention, 2007). pH was determined using the EBC method 9.35, similar to AOAC (2004). Colour presented in ${ }^{\circ} \mathrm{EBC}$ was determined using the Spectrophotometric Method (EBC method 9.6). Apparent extract (AE) presented in $\mathrm{g} / 100 \mathrm{~g}$ was determined using the EBC method 9.43.1. Alcohol by volume (\%ABV) was determined by distillation (EBC method 9.2.1). Turbidity presented in NTU (Nephelometric Turbidity Unit)

A hedonic scale test was used to evaluate the sensory attributes of beer samples according to the method reported by Iwe (2002). This specifically involved comparing the rice malt beer samples with the commercial lager beer. The sensory evaluation was carried out by 20 ordinary frequent beer drinkers (semi-trained panelists) of different age groups (20-36 years old). The prerequisites for participating in the study were that the individual consumed beer and showed interest in participating in all test sessions. Importantly, the participation in this sensory evaluation was voluntary, and oral consent was obtained prior to participation. The coded rice 
388 malt beer samples were randomly served at temperatures of about $10{ }^{\circ} \mathrm{C}$. Participants were

389 served with 4 series of beer samples in transparent glass cups and the degree of liking was rated

390 using a nine-point hedonic scale with the ratings of 9 as liked extremely and 1 as disliked

391 extremely for five main attributes i.e., colour, aroma, taste, mouthfeel and appearance; while

392 overall acceptance of the samples was evaluated by taking the average of other attributes. The

393 panelists drank potable water to rinse/clean their mouth between tastings to avoid cross-

394 contamination between samples. After tasting, score sheets were filled by the tasters.

395 Statistical analysis

396 One-way analysis of variance (ANOVA) was carried out using the IBM SPSS version 20

397 Software (IBM, New York, USA). Results were expressed as mean standard deviation (SD).

398 Mean differences were resolved using the least significant differences (LSD) at post-hoc

399 conditions. The level of statistical significance was considered at $\mathrm{p}<0.05$.

\section{Results}

401 Changes in grain characteristics of rice varieties

402 The grain characteristics of rice varieties is shown in Table 1. Specifically, the grain 403 characteristics were depicted in terms of TKW (g), GE (\%), GC (\%), and DoS (\%). Results 404 showed that TKW, GE, GC, and DoS varied significantly $(\mathrm{p}<0.05)$ across the rice varieties. 405 Further, the TKW ranged between $25.81-27.01 \mathrm{~g}$, GE ranged between $86.50-95.00 \%$, GC 406 ranged between 92.50 - 95.50 \%, and DoS ranged between $49.96-55.00 \%$. Clearly, the TKW 407 peaked at NERICA 7(27.01 g). Additionally, both GE and GC peaked at NERICA 7, with 95.00

$408 \%$, and $95.50 \%$ respectively. Additionally, the DoS was peak (55.00\%) at FARO 44, and least at 409 NERICA 7 (49.96\%). Besides, the rice varieties obtained acceptable grain germination of above $41085 \%$.

411 Changes in CWE, HWE, DP, MY, ML, MC and TN of rice malt

412 The CWE $(\mathrm{g} / 100 \mathrm{~g}), \mathrm{HWE}(\mathrm{L} / \mathrm{kg}), \mathrm{DP}\left({ }^{\circ}\right.$ Lintner$)$ of rice malts subject to varying steeping 413 durations, germination periods, and kilning temperatures are shown in Tables 2, 3, and 4, 414 respectively. Results showed that CWE, HWE, and DP in rice malt varied significantly $(\mathrm{p}<0.05)$ 415 across the varieties. Specifically, the CWE ranged between 10.95 - 23.16 g/100g, HWE ranged 416 between $51.06-206.48 \mathrm{~L} / \mathrm{kg}$, and DP ranged between $22-150^{\circ}$ Lintner, across rice varieties. 
417 With respect to $\mathrm{S}_{18} \mathrm{G}_{3} \mathrm{~K}_{55^{\circ}}{ }^{\circ}\left(18 \mathrm{~h}\right.$ steeping, 3 days germination, $55^{\circ} \mathrm{C}$ kilning), $\mathrm{S}_{30} \mathrm{G}_{2} \mathrm{~K}_{50}{ }^{\circ}(30 \mathrm{~h}$ 418 steeping, 2 days germination, $50^{\circ} \mathrm{C}$ kilning) and $\mathrm{S}_{24} \mathrm{G}_{3} \mathrm{~K}_{55}{ }^{\circ}$ (24 h steeping, 3 days germination, $41955^{\circ} \mathrm{C}$ kilning) combinations, the CWE, HWE, and DP obtained peaks at FARO $44(22.88 \mathrm{~g} / 100 \mathrm{~g}$; $420136.56 \mathrm{~L} / \mathrm{kg} ; 150$ Lintner), FARO 57 (22.13 g/100g;170.18 L $/ \mathrm{kg} ; 148$ ºintner), and NERICA 4217 (23.16g/100g; 206.48 Lo/kg; 143 'Lintner). Based on these CWE/HWE/DP peaks, the SGK 422 (steeping duration, germination periods and kilning temperatures) combinations of rice varieties 423 trended as follows: $\mathrm{CWE}=$ NERICA $7(23.16 \mathrm{~g} / 100 \mathrm{~g})>$ FARO $44(22.88 \mathrm{~g} / 100 \mathrm{~g})>$ FARO 57 $424(22.13 \mathrm{~g} / 100 \mathrm{~g}) ; \mathrm{HWE}=$ NERICA $7(206.48 \mathrm{~L} / \mathrm{kg})>$ FARO $57(170.18 \mathrm{~L} / \mathrm{k})>$ FARO 44. $425(136.56 \mathrm{~L} / \mathrm{kg})$; and DP = FARO 44 (150 ${ }^{\circ}$ Lintner $)>$ FARO 57 (148 ${ }^{\circ}$ Lintner $)>$ NERICA 7 (143 426 Lintner). Outside this specific SGK combinations, the CWE/HWE/DP obtained no peaks. 427 The malt yield (MY), malting loss (ML), moisture content (MC), and total nitrogen (TN) 428 of rice malt samples is shown in Table 5. Results showed that ML and MY of rice malt changed 429 significantly $(\mathrm{p}<0.05)$ across the varieties. The MY ranged between $87.11-92.65 \%$, whereas the ML ranged between $6.03-10.80 \%$. Additionally, the peak (10.80\%) ML and least (87.11 \%) MY can be seen at NERICA 7, whereas the peak MY (92.65\%) and least ML (6.03\%) can be seen at FARO 44. Specifically from FARO $44\left(\mathrm{~S}_{18} \mathrm{G}_{3} \mathrm{~K}_{55^{\circ}}{ }^{\circ}\right)$, FARO $57\left(\mathrm{~S}_{30} \mathrm{G}_{2} \mathrm{~K}_{50}{ }^{\circ}\right)$ and NERICA $7\left(\mathrm{~S}_{24} \mathrm{G}_{3} \mathrm{~K}_{55^{\circ}}\right.$ ), the $\mathrm{MC}$ and $\mathrm{TN}$ of rice malts were determined (also shown in Table 5). Results showed that both MC and TN varied significantly $(\mathrm{p}<0.05)$. Specifically, the $\mathrm{MC}$ of rice malts ranged between $5.19-6.43 \mathrm{~g} / 100 \mathrm{~g}$, whereas the TN of rice malts ranged between $13.10-$ $15.70 \mathrm{~g} / \mathrm{L}$. Additionally, the MC in rice varieties trended as follows: NERICA7 (6.43g/100g) > FARO44 $(5.52 \mathrm{~g} / 100 \mathrm{~g})>$ FARO57 $(5.19 \mathrm{~g} / 100 \mathrm{~g})$, whereas the $\mathrm{TN}$ in rice varieties trended as follows: FARO $44(15.70 \mathrm{~g} / \mathrm{L})>$ FARO $57(14.30 \mathrm{~g} / \mathrm{L})>$ NERICA 7 (13.10g/L). Additionally, the peaks of MC and TN were obtained at NERICA7 (6.43 $\pm 0.14 \mathrm{~g} / 100 \mathrm{~g})$ and FARO44 (15.70 \pm 0.05 $\mathrm{g} / \mathrm{L})$, respectively.

441

444 (glucose, maltose, maltotetraose, maltotriose, raffinose, and sucrose) can be seen, which significantly differed $(\mathrm{p}<0.05)$ across varieties. In particular, the glucose ranged between $10.84-$ $11.63 \%$, maltose ranged between $14.63-15.34 \%$, maltotetraose ranged between $0.44-0.63 \%$, 
448 sucrose ranged between $2.32-2.83 \%$. Additionally, the sugars in rice malt wort trended by

449 varieties as follows: glucose $=$ FARO57 $>$ FARO44 $>$ NERICA7; maltose $=$ FARO57 $>$

450 NERICA7 $>$ FARO 44; maltotetraose $=$ FARO44 $>$ FARO57 $>$ NERICA7; maltotriose $=$

451 NERICA7 $>$ FARO57 $>$ FARO44; raffinose $=$ FARO44 $>$ NERICA7 $>$ FARO57; and sucrose $=$

452 NERICA7 > FARO44 > FARO57. From these, we see that FARO57 obtained peaks at glucose

$453(11.63 \pm 0.71 \%)$ and maltose $(15.34 \pm 0.08 \%)$, FARO44 obtained peaks at maltotetraose $(0.63 \pm 0.04$

$454 \%)$ and raffinose $(0.07 \pm 0.00 \%)$, NERICA7 obtained peaks at maltotriose $(16.40 \pm 0.07 \%)$ and

455 sucrose $(2.83 \pm 0.08 \%)$.

456 The pH, TSN (g/L), Brix (g/100g), KI (\%), FAN (mg/L), DE (g/100g) and OE (g/100g)

457 components of rice malt wort samples is shown in Table 7. Results showed that, whereas Brix,

$458 \mathrm{KI}$ and FAN varied significantly $(\mathrm{P}<0.05)$, the $\mathrm{pH}, \mathrm{TSN}, \mathrm{DE}$, and $\mathrm{OE}$ resembled $(\mathrm{p}>0.05)$, with

459 the following ranges across rice varieties: $\mathrm{pH}$ ranged between $5.30-5.40$, TSN ranged between

4605.40 - $5.80 \mathrm{~g} / \mathrm{L}$, Brix ranged between 13.88 - $16.36 \mathrm{~g} / 100 \mathrm{~g}$, KI ranged between 34.39 - 44.27 \%,

461 FAN ranged between 108.56 - $117.34 \mathrm{mg} / \mathrm{L}$, DE ranged between $37.00-40.00 \mathrm{~g} / 100 \mathrm{~g}$, and OE

462 ranged between 9.68 - $12.66 \mathrm{~g} / 100 \mathrm{~g}$. By rice varieties, therefore, these (above-mentioned)

463 parameters in rice malt wort obtained peaks at FARO44 $(\mathrm{pH}=5.40 \pm 0.38)$, NERIA7 $(\mathrm{TSN}=5.80$

$464 \pm 0.00 \mathrm{~g} / \mathrm{L})$, FARO57 $($ Brix $=16.36 \pm 0.42 \mathrm{~g} / 100 \mathrm{~g})$, NERICA7(KI $=44.27 \pm 0.28 \%$ ), NERICA7 (FAN=

$465117.34 \pm 0.06 \mathrm{mg} / \mathrm{L})$, and FARO57 $(\mathrm{DE}=40.00 \pm 0.82 \mathrm{~g} / 100 \mathrm{~g}) /(\mathrm{OE}=12.66 \pm 0.04 \mathrm{~g} / 100 \mathrm{~g})$.

466 Additionally, these parameters in rice malt wort trended as follows: $\mathrm{pH}=\mathrm{FARO} 44(5.40)>$

467 FARO57/NERICA 7 (5.30); TSN = NERICA 7 (5.80g/L) > FARO 57 (5.60g/L) > FARO 44

$468(5.40 \mathrm{~g} / \mathrm{L}) ;$ Brix $=$ FARO $57(16.36 \mathrm{~g} / 100 \mathrm{~g})>$ FARO $44(14.65 \mathrm{~g} / 100 \mathrm{~g})>$ NERICA 7

$469(13.88 \mathrm{~g} / 100 \mathrm{~g}) ; \mathrm{KI}=\mathrm{NERICA} 7(44.27 \%)>$ FARO 57 (39.16\%) > FARO 44 (34.39\%); FAN =

470 NERICA $7(117.34 \mathrm{mg} / \mathrm{L})>$ FARO $57(112.23 \mathrm{mg} / \mathrm{L})>$ FARO 44 (108.56mg/L); DE = FARO 57

$471(40 \mathrm{~g} / 100 \mathrm{~g})>$ FARO $44(39 \mathrm{~g} / 100 \mathrm{~g})>$ NERICA $7(37 \mathrm{~g} / 100 \mathrm{~g})$; and OE = FARO 57

$472(12.66 \mathrm{~g} / 100 \mathrm{~g})>$ FARO $44(11.15 \mathrm{~g} / 100 \mathrm{~g})>$ NERICA $7(9.68 \mathrm{~g} / 100 \mathrm{~g})$.

473

474 Changes in $\mathrm{pH}$, colour, AE, alcohol content, turbidity, and sensory attributes of rice malt beer

475 The $\mathrm{pH}$, colour $\left({ }^{\circ} \mathrm{EBC}\right), \mathrm{AE}(\mathrm{g} / 100 \mathrm{~g})$, alcohol content (\%ABV) and turbidity (NTU) of

476 rice malt beer samples is shown in Table 8. Results showed that, whereas the alcohol content

477 varied significantly $(\mathrm{P}<0.05)$, the $\mathrm{pH}$, colour, $\mathrm{AE}$ and turbidity resembled $(\mathrm{p}>0.05)$, with the

478 following ranges across rice varieties: $\mathrm{pH}$ ranged between 3.80 - 3.90, colour ranged between

Peer] reviewing PDF | (2020:10:54302:1:1:NEW 16 Jan 2021) 
4793.20 - $3.73{ }^{\circ} \mathrm{EBC}, \mathrm{AE}$ ranged between 4.57 - $4.93 \mathrm{~g} / 100 \mathrm{~g}$, alcohol content ranged between 2.82 $4804.13 \% \mathrm{ABV}$ and turbidity ranged between 4.30 - $4.80 \mathrm{NTU}$. By rice varieties, therefore, these 481 (above-mentioned) parameters in rice malt beer obtained peaks at FARO57 ( $\mathrm{pH}=3.90 \pm 0.59$; 482 colour $=3.73 \pm 0.71^{\circ} \mathrm{EBC}$; and alcohol content $\left.=4.13 \pm 0.18 \% \mathrm{ABV}\right)$, NERICA7 $(\mathrm{AE}=4.93$ $483 \pm 0.54 \mathrm{~g} / 100 \mathrm{~g}$ ), and FARO44 (turbidity $=5.30 \pm 0.01 \mathrm{NTU}$ ). Additionally, these parameters in of 484 rice malt beer trended as follows: $\mathrm{pH}=$ FARO 57 (3.90) > FARO 44 \& NERICA 7 (3.80); colour $485=$ FARO $57\left(3.73^{\circ} \mathrm{EBC}\right)>$ FARO $44\left(3.70^{\circ} \mathrm{EBC}\right)>$ NERICA $7\left(3.20^{\circ} \mathrm{EBC}\right)$; AE $=$ NERICA 7 $486(4.93 \mathrm{~g} / 100 \mathrm{~g})>$ FARO $44(4.59 \mathrm{~g} / 100 \mathrm{~g})>$ FARO $57(4.57 \mathrm{~g} / 100 \mathrm{~g})$; alcohol content = FARO 57 $487(4.13 \% \mathrm{ABV})>$ FARO $44(3.54 \% \mathrm{ABV})>$ NERICA $7(2.82 \% \mathrm{ABV})$; and turbidity $=$ FARO $48844=(5.30 \mathrm{NTU})>$ FARO $57(4.80 \mathrm{NTU})>$ NERICA $7(4.30 \mathrm{NTU})$.

The sensory attributes (colour, aroma, taste, mouthfeel, appearance, and overall acceptability) of rice malt beer samples is shown in Table 9. Importantly, the sensory attributes of rice malt beer was compared with the commercial lager beer. Results showed that colour, taste, mouthfeel, appearance, and overall acceptability of rice malt beer were significantly $(p<0.05)$ less than those of commercial lager beer. Only the aroma of rice malt beer resembled $(\mathrm{p}>0.05)$ that of commercial lager beer. Specific to the rice malt beer, the sensory attributes ranged as follows: the colour ranged between $6.66-6.91$; aroma ranged between $7.54-7.81$; mouthfeel ranged between $6.57-6.96$; appearance ranged between $6.24-6.52$; taste ranged between 7.69-7.87, and overall acceptability ranged between $6.94-7.21$. By rice varieties with respect to this (rice) malt beer, only the sensory attributes of FARO44 obtained peaks, namely: colour $=6.91 ;$ taste $=7.87 ;$ aroma $=7.81 ;$ mouthfeel $=6.96$; appearance $=6.52 ;$ and overall acceptability $=7.21$.

\section{Discussion}

502 Discussion of rice grain

Across the varieties, the TKW rice grain range $(25.81-27.01 \mathrm{~g})$ (Refer to Table 1) competes well with those reported by Osuji et al., (2019), attributable to differences in soil composition, weather condition, moisture content, or grain production/harvest period. TKW could help identify grain/seed density, size, and variety (Tokpah, 2010; Osuji et al., 2019). NERICA 7 might have a higher starch content compared to other rice varieties in this current study. Higher TKW or large grain size could be indicative of high starch content (Ayernor and Ocloo, 2007). The GE $(86.50-95.00 \%)$ and GC $(92.50-95.50 \%)$ of rice grain (Refer to Table 
510 1) suggests it a very promising substitute for barley in brewing, and probably very viable during

511 malting (Adebowale et al., 2010; Osuji et al., 2019). Such variations in GE and GC across the

512 studied rice varieties might be due to influences of (rice) harvest period, kernel size, starch

513 content, water absorption rates. Grain germination of above $90 \%$ portrays a good quality malt

514 attribute (Agbale et al., 2007). Rice varieties obtained acceptable grain germination of above 85

$515 \%$, which makes it acceptable for malting purposes. Similar trends of over $85 \%$ germinative

516 properties are reported elsewhere (Bam et al., 2006; Hammond \& Ayernor, 2001; Ameko et al.,

517 2013). Higher GE enhances the enzyme activities as well as seed vigour (Agbale, 2007). Besides,

518 grain and malting characteristics can help ascertain the cereal as an acceptable substitute for

519 barley.

520 The DoS, which is well-known as the amount of moisture/water absorbed by the grain

521 particularly during the steeping process, remains an integral step in the malting process and

522 accompanied by enzyme development and its associated metabolic influences. In the current

523 work, the DoS was highest (55.00 \%) at FARO 44, and least at NERICA 7 (49.96 \%). Results

524 showed that rice varieties with higher DoS obtained higher MY and lower ML (Refer to Table

525 1), probably due to decreased metabolic processes in the rice varieties of the current study.

526 Besides small kernels taking up more water compared to larger kernels, it is also believed that

527 the grains from inland regions would swell and germinate faster compared to grains from

528 maritime regions (Kunze, 2005).

529 Discussion of rice malt

$530 \quad$ Rice malt's CWE $(10.95-23.16 \mathrm{~g} / 100 \mathrm{~g})$ range of current work (Refer to Table 2) agrees

531 with those reported by Kasetsart (2007) and represents a 'good modification' based on CWE (15

$532-22 \mathrm{~g} / 100 \mathrm{~g}$ ) range data of Briggs (1998), and Briggs et al. (2004). By hydrating the grist during

533 grain modification, cold mashing $\left(20^{\circ} \mathrm{C}\right)$ solubilises enzymatically-degraded compounds (Dahiya

534 et al., 2017). According to European Brewing Convention (EBC) and American Society of

535 Brewing Chemists (ASBC), HWE range of 51.06 - 206.48 L\%/kg (Refer to Table 3) will be

536 equivalent to $\sim 13-54 \mathrm{~g} / 100 \mathrm{~g}$ soluble extract (SE). This would suggest the HWE of current work

537 to be greater than two fold of CWE. Moreover, DP of rice malts (23-150 Lintner) (Refer to

538 Table 4) corroborate with barley $\left(50\right.$ - $150^{\circ}$ Lintner) (BYO (2019a), $\left(35-40^{\circ}\right.$ Lintner)

539 (O’Rourke, 2002a) and sorghum (20 - 23 L) malts (Byrne, Donnelly \& Carrol, 1993). Malt DP

540 range $35-40^{\circ}$ Lintner can convert its own starches (BYO, 2019b) probably with a longer 
541 conversion time. Malt enzymes that degrade starch and obtain high extract yield depict good

542 malt characteristics (Sabramanian et al., 1995; Muoria \& Bechtel, 1998).

543 The CWE, HWE and DP of rice malt increased with steeping duration at FARO 44

$544\left(\mathrm{~S}_{18} \mathrm{G}_{3} \mathrm{~K}_{55^{\circ}}\right)$, FARO $57\left(\mathrm{~S}_{30} \mathrm{G}_{2} \mathrm{~K}_{50}{ }^{\circ}\right)$ and NERICA 7 $\left(\mathrm{S}_{24} \mathrm{G}_{3} \mathrm{~K}_{55^{\circ}}\right)$ (Refer to Tables 1, 2 and 3). DP's

545 significant role in HWE of rice malt, corroborating with data of millet malt (Eneje, Odibo \&

546 Nwani, 2012). Besides small-sized kernel of cereals modifying at a faster rate over large ones

547 (Agu, 2009), the grain physiological activities progressing during malting (Kunze, 2004;

548 Ogbonna, 2002; Osuji, Ofoedu \& Ojukwu, 2019) could influence CWE, HWE and DP of rice

549 malt. Starch-degrading enzymes like alpha-amylase, beta-amylase, limit dextrinase and alpha-

550 glucosidase (Buchholz, Volker \& Uwe, 2005; Evans, Li \& Eglinton, 2010), lipases, proteases

551 and other enzymes (Briggs, 1998) could also influence DP of rice malt. Low DP of rice malts

552 could corroborate with lower protein content of grain (Agu \& Palmer, 1998). Mashing schedule,

553 high gelatinization temperature, and kilning/malting conditions might be contributing to the

554 differences in CWE, HWE and DP of rice malt in this study.

555 To a maltster, MY is an important attribute because it gives an indication of the amount

556 of recoverable soluble extracts from the malted grain (Osuji et al., 2019). The analysis of malt

557 quality guides the maltster/brewer on variety selection and effectiveness of the malting process

558 to optimise output, as well as to achieve sustainable malt brewing process (Briggs, 1998). On the

559 other hand, ML measures the metabolic activity associated with grain germination, which

560 increases with the germination period. In the current work, the MY $(87.11-92.65 \%)$ and ML

$561(6.03-10.80 \%)$ of rice malt changed significantly $(\mathrm{p}<0.05)$ across varieties (Refer to Table 5)

562 with peaks seen at NERICA $7(\mathrm{ML}=10.80 \%)$ and FARO 44 (MY=92.65\%). Probably, these

563 variations in ML and MY might have been influenced by the malting process (Ofoedu, 2018;

564 Osuji et al., 2019). Besides moisture loss during kilning as well as physiological activities

565 associated with germination, the changes in TKW, GE, and GC could also be influenced by both

566 MY and ML. We hold this opinion, given the peak TKW, GE, and GC values obtained at

567 NERICA 7, as well as the least MY obtained at FARO 44 (Comparing Tables 1 and 5).

568 The MC of rice malt $(5.19-6.43 \mathrm{~g} / 100 \mathrm{~g})$ (Refer to Table 5) was above those of Munich

$569(3.0-4.8 \mathrm{~g} / 100 \mathrm{~g})$ as well as two-row $(2.0-4.3 \mathrm{~g} / 100 \mathrm{~g})$ barleys (Noonan, 2003). An increase in

$570 \mathrm{MC}$ of malts can decrease the extract potential, which might lower the original gravity of the

571 wort (BYO, 2019a). Malt closer to $1.5 \mathrm{~g} / 100 \mathrm{~g}$ MC would be of less risk to mould growth 
572 (Noonan, 2003). A decrease in the moisture level of grain can be achieved with increased drying 573 temperature(s) as well as prolonged drying time(s) (Osuji et al., 2019). Whilst low MC can 574 prolong food shelf life (Alozie et al., 2009), a high MC can enhance its microbial spoilage 575 (Ijarotimi, 2012). TN of rice malt $(13.10-15.70 \mathrm{~g} / \mathrm{L})$ (Refer to Table 5) fell within those of 576 ale/lager $(14.00-18.00 \mathrm{~g} / \mathrm{L})$ (O'Rourke, 2002a), and sorghum $(14.70-17.40 \mathrm{~g} / \mathrm{L})$ types (Agu \& 577 Palmer, 1998). Rice variety as well as malting conditions might also be contributing to the MC 578 and TN differences in rice malt of this current work. Besides the amino acids being required for 579 yeast growth, the hydrophobic nitrogen (from malt) provides foam and head retention in beer 580 (O’Rourke, 2002a).

581 Discussion of rice malt wort

582 The importance of sugar wort composition/parameter to the brewer especially for 583 fermentation cannot be over-emphasized. The sugar profile of rice malt wort is the outcome of 584 enzymatic activities during mashing. In the current work, the rice malt wort yielded a

585

586

587

588

589

590

591

592

593

594

595

596

597

598

599

600

601

602 combination of sugars, such as maltose $(14.63-15.34 \%)$, maltotriose $(12.26-16.40 \%)$, glucose $(10.84-11.63 \%)$, sucrose $(2.32-2.83 \%)$, raffinose $(0.05-0.07 \%)$ and maltotetraose $(0.44-0.63 \%)$, all of which varied significantly $(\mathrm{p}<0.05)$ across varieties (Refer to Table 6$)$. Clearly, it was not difficult to differentiate the sugars herein based on the amounts obtained across the studied rice varieties. Specifically, whereas the maltose, glucose, and maltotriose clearly obtained higher amounts, the sucrose, maltotetraose, and raffinose obtained lower amounts. Both maltose and maltotriose, well-known as predominant sugars found in wort are seemed to be noticeably less than the values obtained by Ofoedu et al., (2019).

Malting conditions, mashing program as well as the nature/type of (exogenous) enzymes used could have some impact on the variations in the rice malt wort sugar profile. Additionally, the lower sugar concentrations in the rice malt wort might be attributable to limit dextrins produced in higher amounts, and maybe, tannins binding with malt's amylase enzyme (Okolo et al., 2010). Sucrose, which is among the major soluble sugars and natural components of the matured kernel, was neither produced during malting nor hydrolysis/mashing, but however, could be depleted naturally during germination in sustaining (rice) malt metabolism. This might explain the significantly low sucrose concentration in the rice malt wort. The presence of maltotetraose and raffinose in the wort could be an indication of oligosaccharides resulting from limited dextrins formation due to the different amylolytic enzymes working in the rice malts 
603 (Marconi et al., 2017).

604 Resembling $(\mathrm{p}>0.05)$ across rice varieties $($ FARO $44=5.40>$ FARO57/NERICA $7=$

605 5.30), the $\mathrm{pH}$ of rice malt wort (Refer to Table 7) compares well with a previously published

606 (rice wort) data (4.98 - 6.08) (Kasetsart, 2007) but slightly below those of barley ale/lager (5.6 -

607 5.9) (Palmer, 2006). During mashing and wort boiling, heat treatment can dissociate the calcium

608 ion $\left(\mathrm{Ca}^{2+}\right)$ bound with both phosphates $\left(\mathrm{K}_{2} \mathrm{PO}_{4}\right)$ and polypeptides, forming insoluble compounds,

609 releasing hydrogen ion $\left(\mathrm{H}^{+}\right)$, and decreasing wort $\mathrm{pH}$ (Palmer, 2006). Increased wort acidity

610 enhances both protein coagulation and yeast growth, and inhibits microbial contamination

611 (O’Rourke, 2002b).

612 The TSN of rice malt wort resembled $(\mathrm{p}>0.05)$ across rice varieties (NERICA 7 $=5.80 \mathrm{~g} / \mathrm{L}$

$613>$ FARO $57=5.60 \mathrm{~g} / \mathrm{L}>$ FARO $44=5.40 \mathrm{~g} / \mathrm{L}$ (Refer to Table 7) corroborates favourably with those

614 of sorghum $(5.00-7.00 \mathrm{~g} / \mathrm{L})$ (Agu \& Plamer, 1998) and typical lager barleys $(5.70-6.60 \mathrm{~g} / \mathrm{L})$

615 (O’Rourke, 2002a). Aided by denaturation and precipitation of solubilized proteins, high

616 gelatinization temperature of rice starch reduces TSN level in the wort. Steeping could enhance

617 the loss of some soluble nitrogenous compounds, like amino acids (Briggs, 1998). Amino acid

618 dissolution could increase TSN (during germination) owed to increased activity of protease

619 enzyme (Banusha \& Vasantharuba, 2013), which would cease if acrospires reach from 3/4 to 7/8

620 of grain length (Briggs et al., 2004). As the need for wort TSN increases, it becomes undesirable

621 when protein degradation raises the TSN levels higher than required, thereby causing a reduction

622 in foam formation, abnormal fermentation (Sadosky, 2007), and haze formation (Briggs et al.,

623 2004).

624 The Brix of rice malt wort differed significantly $(\mathrm{p}<0.05)$ across rice varieties (FARO 57

$625=16.36 \mathrm{~g} / 100 \mathrm{~g}>$ FARO $44=14.65 \mathrm{~g} / 100 \mathrm{~g}>$ NERICA $7=13.88 \mathrm{~g} / 100 \mathrm{~g})$ (Refer to Table 7). A peak

626 Brix at FARO 57 suggested increased malting accessibility to the substrate (starch) with

627 enhanced enzymatic hydrolysis. Grain kernel size differences in rice varieties might affect the

628 endosperm starch composition when malted/mashed, which may well vary the Brix values.

629 Varying malting conditions influence the degree of grain response to modification, which could

630 actually differ amongst rice varieties during germination. Brix value could, therefore, be affected

631 by the variety and amount/type of sugars in the wort, which serves as a nutrient for yeast

632 (Pedley, 1996).

633 The KI of rice malt wort differed significantly $(\mathrm{p}<0.05)$ across rice varieties (NERICA 7 
$634=44.27 \%>$ FARO $57=39.16 \%>$ FARO $44=34.39 \%)($ Refer to Table 7$)$ with range its $(34.39-$ $63544.27 \%)$ resembling those of typical lager malt (34 - 44\%) (O’Rourke, 2002a). Malts can be 636 classified, based on the degree of modification (BYO, 2019b), namely: a) under modified (KI 637 values between $30-35 \%$ ), b) well modified (KI values above 35\%), c) over modified (KI values 638 above 45\%) malts. Specifically, wort KI of FARO 44 (34.39\%) falls within 'under modified', 639 whereas FARO 57 (39.16\%) and NERICA 7 (44.27\%) falls within 'well modified 'malts.

640 Further, Bamforth (2003) reported 'well modified 'malt with KI range of $38-42 \%$. Besides 641 malting enabling KI to increase with germination, the small-size of FARO 44 kernel may 642 corroborate with lower (KI) value. Thinner kernel/grain size taking up water faster (Kunze, 643 2004; Osuji et al., 2019) might sustain a higher TN relative to the larger ones (Briggs, 1998). The 644 reduced HWE, CWE and KI values might help in defining those of FARO 44 as 'under modified 645 malt'. Howbeit, NERICA 7 higher TSN (5.80g/L) and KI values (44.27\%) would suggest a 646 positive association of grain size with HWE, CWE and TSN of the current study.

647 The FAN of rice malt wort differed significantly $(\mathrm{p}<0.05)$ across rice varieties (NERICA $6487=117.34 \mathrm{mg} / \mathrm{L}>$ FARO $57=112.23 \mathrm{mg} / \mathrm{L}>$ FARO $44=108.56 \mathrm{mg} / \mathrm{L})($ Refer to Table 7$)$, and 649 compared well with those of sorghum (94 - 216 mg/L) (Agu \& Palmer, 1998), maize (100 $650169 \mathrm{mg} / \mathrm{L})$ and rice $(95$ - 138mg/L) (Taylor, Dlamini \& Kruger, 2013) malts. Increased amino 651 acids/protein modification might favour the peak FAN in NERICA 7 with proteolytic enzyme 652 activity. As the principal nitrogen source in the wort, FAN depicts hydrolysed (soluble) proteins 653 during mashing (Agu \& Palmer, 1998; Russell, 2006), summed up by amino acids, ammonium 654 ions and small peptides (dipeptides and tripeptides) (Stewart, Hill \& Lekkas, 2013; Lekkas et al., 655 2005; Pugh, Maurer \& Pringle, 1997). Typical lager malt with FAN between 100 and 140mg/L 656 can enhance both efficient yeast cell growth and fermentation performance (Lekkas et al., 2005), 657 in order to achieve a trouble-free fermentation (Briggs et al., 2004). Besides, FAN can also help 658 to predict yeast's healthy growth, viability/vitality, and fermentation efficiency (Hill \& Stewart, 659 2019). Though FAN strongly depends on malting conditions (Briggs, 1998), some FAN 660 components (alongside reducing sugars) during mashing might provide minor flavour precursors 661 that undergo Maillard reaction (Hill \& Stewart, 2019; Hughes, 2009). Despite FAN influencing 662 other fermentation factors (like cell biomass, growth, $\mathrm{pH}$, viability, and attenuation rate)

663 (Shimizu et al., 2002), too high FAN is undesirable given the resultant excessive yeast growth, 664 which could affect beer stability (BYO, 2019b). Malts with higher FAN levels require adjuncts, 
665 which can act as nitrogen diluent but would contribute little-to-no TSN to the wort (Briggs et al., 666 2004).

667 Resembling ( $>0.05$ ) across rice varieties (FARO 57=40g/100g $>$ FARO 44=39g/100g

$668>$ NERICA $7=37 \mathrm{~g} / 100 \mathrm{~g}$ ), the peak DE of rice wort (Refer to Table 7) suggested increased

669 hydrolysis. Slight DE variations in wort might reflect the differences in the amylose-amylopectin

670 ratio of rice starch. This is because the amylose can be more completely hydrolyzed than

671 amylopectin, the latter limited by beta-limit dextrin due to branched chains (Osuji \& Anih,

672 2011). Varietal differences, varying malting conditions as well as amount/type of enzymes

673 developed in the rice grain particularly during malting might also govern the degree of

674 hydrolysis and hydrolysates types obtained. The maltose and maltotriose remain the most

675 abundant sugars present in malt/wort (Goldhammer, 2008; Palmer, 2009), which could also

676 influence the DE of wort (Ofoedu et al., 2020).

677 Resembling $(\mathrm{p}>0.05)$ across rice varieties (FARO 57=12.66g/100g $>$ FARO 44= 11.15

$678 \mathrm{~g} / 100 \mathrm{~g}>$ NERICA $7=9.68 \mathrm{~g} / 100 \mathrm{~g}$ ), OE of rice malt wort (Refer to Table 7 ), neared those of

679 millet $(\sim 10 \mathrm{~g} / 100 \mathrm{~g})$, sorghum $(10.42 \mathrm{~g} / 100 \mathrm{~g})$ and barley $(11.0 \mathrm{~g} / 100 \mathrm{~g})$ malts (Reginald, 1995),

680 and compared well with other reported ranges $(7.5-9,8-9.5,11-14$, and $12.5-16 \mathrm{~g} / 100 \mathrm{~g})$ of

681 different barleys used for ale beers (Papazian, 2006). Principally, original gravity (density) of the

682 wort is four times the original extract by Plato scale. Well-known, water density is 1.0000 at

683 standard temperature and pressure (STP); if respective wort density of FARO 44, FARO 57 and

684 NERICA 7 were 1.04448 (11.15 g/100g), $1.05064(12.66 \mathrm{~g} / 100 \mathrm{~g})$ and $1.03872(9.68 \mathrm{~g} / 100 \mathrm{~g})$, the

685 corresponding wort will be $44.48 \mathrm{o}, 50.64 \mathrm{o}$, and $38.72 \mathrm{o}$ of excess gravity. Thus, wort densities

686 would consider the solution factors/mixtures of dissolved carbohydrate materials, soluble

687 proteins and minerals that typically emerge from malted cereal materials. Though grain mashing 688 considerably influences OE of wort, most grain modified products (that is, cell wall degradation 689 and enzymatic breakdown) in endosperm's protein-starch matrix (Agu \& Palmer, 2001) would be 690 released (into the wort) as soluble extracts.

691 Discussion of rice malt beer

692 Resembling $(\mathrm{p}>0.05)$ across rice varieties (FARO 57=3.90 $>$ FARO 44 \& NERICA 7= 693 3.80), $\mathrm{pH}$ of beer (Refer to Table 8) appeared lower than those of barley (4.1 - 4.5) (Bamforth, 694 2001) as well as sorghum (3.90 - 4.10) beers (Iwouno, Ofoedu \& Ofoedum, 2019). Low pH in 695 rice malt beer might be due to organic (weak) acids excreted by yeast with excess $\mathrm{CO}_{2}$ (which 
696 provides relative amounts of carbonic acid) during fermentation. Low beer $\mathrm{pH}$ also depicts its

697 sharpness of taste. When $\mathrm{pH}$ is below 4, taste further sharpens with increased foam stability and

698 head retention (Bamforth, 2009). By decreasing buffering capacity, lower $\mathrm{pH}$ increases yeast

699 growth, removes colloidal particles of proteins-polyphenol complexes (and other insoluble

700 materials) and inhibits microbial growth (in beer/wort) (Leiper \& Miedl, 2006). In addition, pH

701 in beer, determined by organic acids, e.g., acetic, lactic, pyruvic and citric acid, can influence its

702 flavour.

703 The depiction of beer colour is largely based on appearance, which remains critical to 704 (product) acceptance. Importantly, this has largely been the among the first quality attributes 705 beer consumers perceive (Leon, Mery, Pedreschi, \& Leon, 2006; Osuji, Ofoedu, Omeire \& 706 Ojukwu, 2020). Beer colour resembled ( $\mathrm{p}>0.05)$ across rice varieties (FARO $57=3.73^{\circ} \mathrm{EBC}>$ 707 FARO $44=3.70{ }^{\circ} \mathrm{EBC}>$ NERICA $7=3.20^{\circ} \mathrm{EBC}$ ) (Refer to Table 8). Although fairly above 708 those of another rice malt $\left(1.70-2.60^{\circ} \mathrm{EBC}\right)$ (Mayer et al., 2017), rice malt beer herein 709 compared well with those of typical barley $\left(2.00-4.00^{\circ} \mathrm{EBC}\right)$ (O'Rourke, 2002a), but not so for 710 sorghum $\left(6.0-6.6^{\circ} \mathrm{EBC}\right)$, barley double crown $\left(\sim 7.5^{\circ} \mathrm{EBC}\right)$ and barley rex $\left(\sim 14.0^{\circ} \mathrm{EBC}\right)$ malt 711 lager beers (Olatunji et al., 1993). It is largely understood that as ${ }^{\circ} \mathrm{EBC}$ increases, the beer colour 712 gets darker. When assessed by the Saveur Bierre colour chart (Anon., 2020), the range of rice 713 malt beer colour of the current study was perceived as pale yellow lager. Beer colour variations 714 could be as a result of either decolourization of the (beer colour) substance as $\mathrm{pH}$ dropped

715 (Kunze, 2004), changes/differences in malt colour, or inconsistencies in the colour formation of 716 wort during boiling process (Briggs et al., 2004). Phenols (tannins) are natural organic 717 compounds in malts/hops, which change beer colour from pale yellow to dark brown via 718 Maillard reaction/caramelization (Whistler \& Bemiller, 2008; Panthare, Opara \& Al-Said, 2013). 719 In addition, Maillard reaction and caramelization occurring independently/simultaneously would 720 influence colour formation/intensity (Kunze, 2004). Other factors like $\mathrm{pH}$ level, yeast strain, hop usage, maturation duration, and specialty ingredients can influence beer colour.

$\mathrm{AE}$ resembled across rice varieties ( $\mathrm{p}>0.05$ ) (NERICA $7=4.93 \mathrm{~g} / 100 \mathrm{~g}>$ FARO $44=4.59$

$723 \mathrm{~g} / 100 \mathrm{~g}>$ FARO $57=4.57 \mathrm{~g} / 100 \mathrm{~g})($ Refer to Table 8$)$. Noticeably, there appears some reduction 724 in gravity of wort from $9.68-12.66 \mathrm{~g} / 100 \mathrm{~g}$ (Table 4) to $4.57-4.93 \mathrm{~g} / 100 \mathrm{~g}$ (Table 5 ) in the final 725 rice malt beer. Dissolved solids (sugars, amino acids, minerals, among others) in wort utilized by 726 yeast during fermentation might reduce the final beer gravity. As yeast utilizes sugars (and other 
727 compounds) to produce alcohol, the gravity of wort may well decrease (Boulton, 1991; Briggs et 728 al., 2004). Moreover, fermentability of wort depicts the proportion of dissolved solids (extract) 729 that can be fermented. In other words, $59 \%$ (FARO 44), $64 \%$ (FARO 57) and $49 \%$ (NERICA

730 7) of fermentable materials in these worts utilized by yeast produced AE of $4.59 \mathrm{~g} / 100 \mathrm{~g}, 4.57$ $731 \mathrm{~g} / 100 \mathrm{~g}$ and $4.93 \mathrm{~g} / 100 \mathrm{~g}$, respectively.

732 Alcohol content of beer, although differing significantly $(\mathrm{p}<0.05)$ across rice varieties 733 (FARO $57=4.13 \%$ ABV $>$ FARO $44=3.54 \%$ ABV $>$ NERICA $7=2.82 \% A B V$ ) (Refer to Table 734 8), fell within a generally anticipated range (4 - 6 \%ABV) (Polan, Eisner \& Vytras, 2015), 735 somewhat above $2.55,3.09$ and $3.65 \% \mathrm{ABV}$ of millet, sorghum and barley beers, respectively (Reginald, 1995). FARO 57 with peak fermentability of $64 \%$ corresponded to $4.13 \% \mathrm{ABV}$, and NERICA 7 with least fermentability of $49 \%$ corresponded to $2.82 \% \mathrm{ABV}$. This suggests that 738 alcohol concentration in beer does not solely depend on the original extract/gravity of wort, but more likely on the availability of fermentable extracts, readily utilized by the yeast. Whilst the fermentable extracts especially sugars in wort remain the beer quality index (Jordao, Vilela \& Cosme, 2015), its concentration (and subsequent utilisation) in the wort can help to determine the improved fermentation efficiencies (Zhao et al., 2008).

Resembling ( $>0.05$ ) across rice varieties (FARO $44=5.30 \mathrm{NTU}>$ FARO $57=4.80 \mathrm{NTU}$ $>$ NERICA $7=4.30 \mathrm{NTU}$ ), beer turbidity (Refer to Table 8 ) were above those of sorghum (1.6 2.0NTU) and barley malt (3.2NTU) lager beer (Olatunji et al., 1993), but below those of sorghum (red) (South Africa) ( 12.8 NTU), sorghum (white) (Australia) ( 28 NTU), sorghum (white) (Nigeria) ( 33.2 NTU) malt beers (Aisen \& Muts, 1987), and sorghum beer clarified with different filter aids (8.28 - 26.56 NTU) (Iwouno et al., 2019). Considering 1.00 EBC equals 4.00 NTU, the beer turbidity can be graded based on degree of haziness, which includes; brilliant: $0-0.50$ EBC $(0-2.00 \mathrm{NTU})$; almost brilliant: $0.50-1.00$ EBC (2.00 - $4.00 \mathrm{NTU})$; very slightly hazy: $1.00-2.00 \mathrm{EBC}(4.00-8.00 \mathrm{NTU})$; slightly hazy: $2.00-4.00 \mathrm{EBC}(8.00-$ 16.00 NTU); hazy: $4.00-8.00 \mathrm{EBC}(16.00-32.00 \mathrm{NTU})$ and very hazy: $>8.00 \mathrm{EBC}(>32.00$ NTU) (Callemien \& Collin, 2009). Herein, the rice malt beer (4.30 - 5.30 NTU) would be considered as 'very slightly hazy' (Refer to Table 8). Some proteins not removed during wort boiling, surviving fermentation, and finding its way into the beer, might equally cause the haze (Briggs et al., 2004). Besides the origin of haze formation as either biological (e.g., bacteria, cell debris, yeast) or non-biological (inorganic, carbohydrate-based and protein-polyphenol 
758 complexes) (Siebert, Carrasco \& Lynn, 1996; Stewart, 2004; Briggs et al., 2004), beer haziness

759 might be due to ineffective filtration, non-flocculant yeast, and or poorly modified malt/filter

760 aids (Steiner, Becker \& Gastl, 2010). Coloured compounds such as melanoidins (Iwouno et al.,

761 2019), cereal/malt-type, and differences in chemical composition/processing methods can

762 influence beer turbidity. In addition, centrifugation and microfiltration used during commercial

763 production can also increase beer clarity (Kuiper et al., 2002; Shotripuk et al., 2005).

764 The sensory attributes (colour, aroma, taste, mouthfeel, appearance, and overall

765 acceptability) of rice malt beers compared well with commercial lager beer (Refer to Table 9).

766 Based on the hedonic scale, the panelists viewed the colour of the rice malt beers $(6.66-6.91)$ as

767 pale yellow colour and compared to the commercial lager beer (8.71). The panelists considered

768 the rice malt beers as slightly liked compared to the commercial lager beer that was liked very

769 much. The colour variations in the beer samples may be due to differences in kilning

770 temperatures and chemical compositions (sugars and amino acids) that facilitate the formation of

771 melanoidin in beer (Osuji et al., 2020; Iwouno et al., 2019). The panelists obtained the mouthfeel

772 of rice malt beers $(6.57-6.96)$ as slightly liked/relatively flat compared to the commercial lager

773 beer (8.51) which was liked very much. The variations in the mouthfeel of beer samples may be

774 due to varying concentrations of residual sugars, higher alcohols as well as organic acids in the

775 beer (He et al., 2014; Iwouno, Ofoedu \& Aniche, 2019).

776 We opine that the appearance of rice malt beer particularly from the consumer's quality

777 perspective, which itself could also include but not limited to the absence as well as colour of

778 haze, would greatly affect beer perception. Similar to the mouthfeel and colour of beer samples,

779 the appearance $(6.24-6.52)$ of rice malt beer samples was slightly liked probably because the

780 rice malt beers appeared very slightly hazy compared to the commercial lager beer (8.61) which

781 appeared almost brilliant in clarity (Refer to Table 9). The variations in appearance could be due

782 to differences in brewing technology adopted. Notably, the taste and aroma across the beer

783 samples resembled ( $>0.05$ ), although the sensory scores indicated the taste and aroma of

784 commercial lager beer as liked very much, whereas that of rice malt beer samples were liked

785 moderately (Refer to Table 9). Specifically, the aroma and taste of beer are characterized by

786 volatile compound profile (Marconi et al., 2017) influenced principally by yeast metabolism. The

787 differences in taste and aroma of beer samples may occur with fermentation by-products, such as

788 aroma-active esters, higher alcohols, and aldehydes (He et al., 2014; Ferreira \& Guido, 2018). 
789 The overall acceptance herein suggests sensory properties of beer might be affecting consumer

790 liking, considering the commercial lager beer was liked very much by the panelists. Besides

791 FARO 44 and NERICA 7 beer being liked moderately, the FARO 57 beer was slightly liked.

792 Overall, the sensory profile of rice malt beer resembled that of commercial lager beer in aroma

793 and taste, but flatter in mouthfeel (Refer to Table 9).

794 Conclusions

795

The characteristic changes in malt, wort and beer from different locally produced (Nigeria) rice varieties as influenced by varying malting conditions were investigated. The rice varieties exhibited desirable gain quality characteristics and showed acceptable aptitude to be malted due to their germinative property of greater than $85 \%$. Malting conditions significantly influenced the CWE, HWE, DP, MC and TN of rice malt. Across varieties, the $\mathrm{pH}$, TSN, Brix, $\mathrm{KI}, \mathrm{FAN}, \mathrm{DE}$, and $\mathrm{OE}$ in rice malt wort, and $\mathrm{pH}$, colour, $\mathrm{AE}$ and turbidity in rice beer resembled $(\mathrm{p}>0.05)$, but not so in $\% \mathrm{ABV}(\mathrm{p}<0.05)$. In addition, the rice malt beer, very slightly hazy, represented a pale yellow light lager. To obtain wort that makes an alcohol clear-beer, requires the addition of exogenous enzymes, particularly in the mashing of rice malts. Moreover, malting improves hydrolysis, modifies the starchy (rice) endosperm, and allows adequate production of FAN, TSN and other fermentable extracts in the wort. Besides the sensory profile differing in appearance, the characteristic pale yellow rice malt beer resembled the commercial lager beer in aroma and taste, but more flat in mouthfeel. Overall acceptance suggest that rice malt beer from FARO 44 was preferred more amongst other rice malt beers, after the commercial lager beer. Although from the sensory observations, we see that the rice malt beer would differ from the commercial lager beer, we still believe the rice malt beer stands a chance to provide its own eccentric beer style. In addition to increasing the DP of rice malt (which has been demonstrated as dependent on both (rice) variety and varying malting conditions), varying malting conditions

813 with respect to (rice) variety could play a vital role in reducing the cost of exogenous enzymes,

814 particularly if the aim is to actualize an all-rice gluten-free beer. Another aspect of this study that 815 we consider very important is the use of blends of rice malt as specialty ingredient (and not as an 816 adjunct) together with barley malts in mashing/brewing, which has the potential to help save the 817 cost of barley malt imports, as well as reduce the singular dependency on barley (temperate crop) 818 for tropical brewing. 
820 lager beer production. Further research is warranted on other locally available rice varieties as

821 well as underutilized cereals for malting/brewing, which would target higher extract yield as well

822 as a clearer beer. However, there is a chance that not all the local rice varieties (in Nigeria as

823 would be the case for future studies) would be suitable for brewing. Therefore, a careful and

824 thorough variety selection would be needful if an optimised malt beer output is to be actualised.

825 Another research direction of future studies could determine the foam formation, retention,

826 bubble size, and distribution as well as microbiological analysis of rice malt beer from selected

827 malting conditions. It is also recommended that future studies could quantitatively and

828 qualitatively determine and characterize enzymes in rice malts of different varieties affected by

829 varying malting conditions.

830

831 CONFLICT OF INTEREST

832 Charles Odilichukwu R. Okpala is an Academic Editor of PeerJ.

\section{AUTHOR CONTRIBUTIONS}

834 CEO, CQA, JOI and CDO conceived/conducted the study and prepared initial manuscript

835 draft. IS and CORO revised manuscript draft and strengthened the scientific interpretation. All

836 authors contributed to the intellectual content and confirmed the final submitted version.

\section{FUNDING}

838 CORO appreciates the funding from Wrocław University of Environmental and Life Sciences, 839 Poland.

\section{REFERENCES}

841 Ackley, D. (2018). What is Diastatic Power? Definition and Chart. In: Eckraus.

842 https://blog.eckraus.com/what-is-diastatic-power-definition-chart. Accessed March 20, 8432020.

844 Agu, R.C. (2009). Corn size distribution, Cold water extract and Diastatic power

845 in relation to Malted barley quality. Technical Quarterly Master Brewers Association of

846 the Americas, pp. 1-7. https://doi.org/10.1094/TQ-46-1-0226-01

847 Agu, R.C. \& Palmer, G.H. (1998). A reassessment of sorghum for Lager beer

848 Brewing. Bioresource Technology 66: 253-261. https://doi.org/10.1016/S0960-

$849 \quad 8524(98) 00047-9$

850 Agu, R.C. \& Palmer, G.H. (2001). The effect of Nitrogen level on the 
851

852

853

854

855

856

857

858

859

860

861

862

863

864

865

866

867

868

869

870

871

872

873

874

875

876

877

878

879

880

881

performance of malting Barley varieties during germination. Journal of Institute of Brewing 107(2): 93-98.

https://doi.org/10.1002/j.2050-0416.2001.tb00081.x

Aisen, A.O., \& Muts, G.C.J. (1987). Micro-scale Malting and Brewing Studies of Some Sorghum Varieties. Journal of Institute of Brewery 93: 328-331.

Alozie, Y.E., Iyam, M.A., Lawal, O., Udofia, U, \& Ani, I.F. (2009). Utilization of Bambara ground flour blends in bread production. Journal of Food Technology 7(4):111114.

AOAC (2004). Association of Official Analytical Chemists. Official methods of analysis (18th ed.), Arlington, VA: AOAC International.

AOAC (2006). Association of Official Analytical Chemists. Official methods of analysis - 982.14 (18 $8^{\text {th }}$ ed.), Maryland: AOAC International.

Anon. (2020). EBC-Estimating Beer Colour? In: White, Blonde, Ruby, Brown: Beer in every Colour. https://www.saveur-biere.com/en/magazine/brewing/4/white-blonde-ruby-brownbeer-in-every-colour/58 Accessed on May 26, 2020.

Asare, E.K., Jaiswal, S., Maley, J., Baga, M., Sammynaiken, R., Rossnagel, B.G. \& Chibbar, R.N. (2011). Barley grain constituents, starch composition, and structure affect starch in vivo enzymatic hydrolysis. J, Agric. Food Chem. 59: 47434354.

ASBC (2009). Methods of Analysis Preface to Table 1: Extract in Wort and Beer, American Society of Brewing Chemists, St Paul.

Ayerno, G.S. \& Hammond, T.K (2000): Combination of malted cereals and cassava a starch in the production of sugar syrup. Journal Ghana Science Association 2(1):87-92. https://doi.org/10.4314/jgsa.v2i1.17844

Badau, M.H., Jideani, I.A. \& Nkama, I. (2006). Amylase activities and values in hot and cold water extracts of pearl millet. Journal of Applied Glycoscience 53: 1-6. https://doi.org/10.5458/jag.53.1

Bamforth, C.W. (2001). pH in brewing: An Overview Technology. Technical Quarterly of Masters Brewers Association of the Americas 38: 1-9.

Bamforth, C.W. (2003). Beer: Tap into the art and science of brewing. $2^{\text {nd }}$ 
882 Edition, Oxford University Press, USA.

883 Bamforth, C.W. (2006). Barley and Malting. In: Scientific Principles of Malting

884 and Brewing. St. Paul, MN: American Society of Brewing Chemists. Pp. 21-44.

885 Banusha, S. \& Vasantharuba, S. (2013).Effect of Malting on Nutritional Contents

886 of Finger millet and Mungbean. American-Eurasian Journal of Agriculture \&

887 Environmental Science, 13(12): 1642-1646.

888 Beeradvocate (2020). Lager-Japanese Rice. In: Beer Styles.

889 https://www.beeradvocate.com/beer/styles/169/ Accessed on December 10, 2020.

890 Boulton, C.A. (1991). Development in Brewery Fermentation. Biotechnology and

$891 \quad$ Genetic Engineering Reviews, 9(1): 127-182.

$892 \quad$ https://doi.org/10.1080/02648725.1991.10647879

893 Briess (2020). Amaze (ake) Me Japanese Pilsner. In: Briess Malt and Ingredients.

894 http://www.brewingwithbriess.com/Recipes/beer/display/amaze-ake-me-japanese-pilsner

895 Accessed on December 18, 2020.

896 Briggs, D.E. (1998). Malts and Malting. 1st Edition Blackie Academic and

897 Professional, London. P. 596.

898 Briggs, D.E., Brookes, P.A., Stevens, R. \& Boulton, C.A. (2004). Science of

899 Mashing. In: Brewing Science and Practice. Woodhead Publishing Limited, England. P.

900 86. https://doi.org/10.1201/9780203024195.ch4

901 Broadbent, R.E. \& Palmer, G.H. (2001). Relationship between $\beta$-amylase

902 activity, steeliness, mealiness, nitrogen content and nitrogen fraction of barley grains.

903 Journal of Institute of Brewing 107: 349-354. https://doi.org/10.1002/j.2050-

904 0416.2001.tb00103.x

905 Buchholz, K., Volker, K. \& Uwe, T.B. 92005). Introduction to enzyme technology.

906 In: Biocatalysts and Enzyme Technology. Weinheim, Germany: Wiley-VCH. Pp. 1-25.

907 BYO (2019a). Understanding Malt Spec Sheets. In: Brew Your Own.

908 https://byo.com/article/understanding-malt-spec-sheets-advanced-brewing/ Accessed on

$909 \quad$ May 5, 2020.

910 BYO (2019b). Master Malt Analysis. In: Brew Your Own.

911 https://byo.com/article/master-malt-analysis/ Accessed on May 5, 2020.

912 Byrne, H., Donnelly, M. F. \& Carrol, M. B. (1993). A comparison of some 
913

914

915

916

917

918

919

920

921

922

923

924

925

926

927

928

929

930

931

932

933

934

935

936

937

938

939

940

941

942

943

properties of barley, wheat, triticale and sorghum malts. In Proceedings of the Fourth Scientific and Technical Convention of the Institute of Brewing, Central and Southern African Section, Somerset West,

Callemien, D. \& Collin, S. (2009). Structure, Organoleptic Properties, Quantification Methods and Stability of Phenolic Compounds in Beer - A Review. Food Reviews International 26(1): 1-84. https://doi.org/10.1080/87559120903157954

Cela, N., Condelli, N., Caruso, M.C., Perretti, G., Cairano, M.D., Tolve, R. \& Galgano, F. (2020). Gluten-Free brewing: Issues and Perspectives. Fermentation, 6(53): 1-26. https://doi.org/10.3390/fermentation6020053

Contreras-Jimenez, B., Real, A.D., Millan-Malo, B.M., Gaytan-Martinez, M., Morales- Sanchez, E. \& Rodriguez-Garcia, M.E. (2018). Physicochemical changes in barley starch during malting. Journal of Institute of Brewing 125(1): 1-8. https://doi.org/10.1002/jib.547

Dahiya R, Yadav R.B, Yadav B.S \& Yadav R. (2018). Quality Characteristics of Pearl Millet Malt as affected by Steeping Temperature and Germination Period. Quality Assurance and Safety of Crops \& Foods, 10(1): 41-50. https://doi.org/10.3920/QAS2016.0930

Daneri-Castro, S.N., Svensson, B. \& Roberts, T.H. (2016). Barley Germination: Spatio-temporal consideration for designing and interpreting omics experiments. Journal of Cereal Science 70: 29-37. https://doi.org/10.1016/j.jcs.2016.05.012

Daoui, A. (2018). Which Country is the Largest Producer of Rice in Africa? Created in 2018. https://www.google.co.uk/amp/s/www.waystocap.com/blog/which-country-is-the-largestproducer-of-rice-in-africa/amp/ Accessed 08 June, 2020.

Dewar, J., Taylor, J.R.N \& Berjak, P. (1997). Determination of improved steeping conditions for Sorghum malting. Journal of Cereal Science 26:129.-136. https://doi.org/10.1006/jcrs.1996.0101

Dziedzic, S. Z. \& Kearsley, M. W. (1995). Handbook of starch hydrolysis products and their derivatives. London: Blackie Academic and Professional. Pp. 65-67, 230.

Eneje, L.O., Odibo, F.J.C. \& Nwani, C.D. (2012). Diastatic power and hot water 
944

945

946

947

948

949

950

951

952

953

954

955

956

957

958

959

960

961

962

963

964

965

966

967

968

969

970

971

972

973

974

extract development during malting of two Nigerian millet varieties. World Journal of Diary and Food Science, 7(2): 181-184.

European Brewery Convention (1998): Analytica $-E B C .5^{\text {th }}$ edition. Extract of Malt. Congress Mash (AM) Method 4.1 Fermentable Carbohydrate in Wort by HPLC Method; Free Alpha Amino Nitrogen.

European Brewery Convention (2006). Analytical-EBC. $6^{\text {th }}$ edition. Verlag Hans Carl Getrankeachverlag, Nuruburg, Germany.

European Brewery Convention. (2007). Analytica-EBC, 5th ed.; Fachverlag Hans Carl: Nürnberg, Germany.

Evans, D.E., Li, C.\& Eglinton, J.K. (2010). The properties and genetics of barley malt starch degrading enzymes in Genetics and improvement of barley malt quality. Springer, Berlin. pp. 143-189. https://doi.org/10.1007/978-3-642-01279-2_6

Ferreira, I.M. \& Guido, L.F. (2018). Impact of wort amino acids on beer flavour: A review. Fermentation, 4(23): 1-13. http://doi.org/10.3390/fermentation4020023

Garzon, A.G., Torres, R.L. \& Drago, S.R. (2016). Effects of malting conditions on enzyme activities, chemical, and bioactive compounds of sorghum starchy products as raw material for brewery. Starch, 68: 1-7.

Goldhammer, T. (2008). The Brewer's Handbook: The complete Book to brewing beer. $2^{\text {nd }}$ ed., Apex Publishers.

Gupta, M., Abu-Ghannam, N., \& Gallaghar, E. (2010). Barley for Brewing: Characteristic Changes during Malting, Brewing and Applications of its By-Products. Comprehensive Reviews in Food Science and Food Safety 9: 318-328.

Hassani, A., Zarnkow, M. \& Becker, T. (2013). Influence of malting conditions on sorghum (Sorghum bicolor (L.) Moench) as a raw material for fermented beverages. Food Science and Technology International, 20(6): 1-12.

He, Y., Dong, J., Yin, H., Zhao, Y., Chen, R.,Wan, X., Chen, P., Hou, X., Liu, J. \& Chen, L. (2014). Wort composition and its impact on the flavour-active higher alcohol and ester formation of beer - a review. Journal of Institute of Brewing, 120 (3): 157-163. http://doi.org/10.1002/jib.145

Hill, A.E. \& Stewart, G.G. (2019). Free Amino Nitrogen in Brewing. Fermentation, 5(22): 1-11. https://doi.org/10.3390/fermentation5010022 
975 Hughes, P. (2009). Beer flavour. In: Beer: A Quality perspective -Handbook of

976

977

978

979

980

981

982

983

984

985

986

987

988

989

990

991

992

993

994

995

996

997

998

999

1000

1001

1002

1003

1004

1005

Alcoholic Beverages series. https://doi.org/10.1016/B978-0-12-669201-3.00002-6

Ijarotimi, O. S. (2012). Influence of germination and fermentation on chemical composition, protein quality and physical properties of wheat flour (Triticum aestivum). Journal of Cereals and Oil seeds, 3(3): 35-47.

Index Mundi. (2020). United States Department of agriculture. Nigeria milled rice imports by year. Retrieved from https://www.indexmundi.com/agriculture/?countryng\&commoditymilledrice\&graphimports

Institute of Brewing (IOB) (2007). Recommended methods of analysis. J. Inst. Brew., 7: 54-76

International Starch Institute (ISI) (1999). Determination of Reducing Power and DE by Lane and Eynon's method. International Starch Institute. Science Park Aarhus, Denmark.

Iwouno, J.O. \& Ojukwu, M. (2012). Effects of experimental variables on the malting quality of Nigerian yellow maize (Zea mays), farz 27 variety. African Journal of Food Science and Technology 3(10): 252-259.

Iwouno, J.O., Ofoedu, C.E. \& Aniche, V.N. (2019). Evaluation of the Prevalence of Congeners from Distilled Spirits of Different Sources. Asian Food Science Journal 7(3): 1-12. http://doi.org/10.9734/AFSJ/2019/v7i329970

Iwouno, J.O., Ofoedu, C.E. \& Ofoedum, A.F. (2019). Potentials of egg shell and snail shell powder in sorghum beer clarification. Archives of Current Research International, 16(4): 1-10. https://doi.org/10.9734/acri/2019/v16i430093

Iwouno, J.O., Ofoedu, C.E, Ugwuegbulam, A.O. \& Nwokoro, O.M. (2019). Evaluation of Dealcoholized Beverage from Pineapple Wine and Sorghum Beer. Current Journal of Applied Science and Technology, 33(5): 1-10. http://doi.org/10.9734/CJAST/2019/v33i530095

Jones, B.L. (1999). Malt Endoproteinases and How They Affect Wort Soluble Protein Levels. Australian Barley Technical Symposium. The regional institute online publishing. http://www.regional.org.au/au/abts/1999/jones.htm Accessed April 19, 2020. Jordao, A.M., Vilela, A. \& Cosme, F. (2015). From sugars of grape to alcohol 
1006

1007

1008

1009

1010

1011

1012

1013

1014

1015

1016

1017

1018

1019

1020

1021

1022

1023

1024

1025

1026

1027

1028

1029

1030

1031

1032

1033

1034

1035

1036

of wine: Sensorial Impact of Alcohol in wine. Beverages 1(4): 292-310. https://doi.org/10.3390/beverages1040292

Kasetsart J. (2007). Malt and Wort Characteristics of 42 Cereal Rice Varieties Cultivated in Thailand. Faculty of Biotechnology, Rangsit University, Pathum Thani 12000, Thailand. Natural Science, 41: $15-20$.

Kohorn, B.D. (2000). Plasma membrane cell wall contacts. Plant physiology, 124: 3138.

Koleoso, O.A., \& Olatunji, O. (1992). Sorghum malt/adjunct replacement in clear (lager) beer: policy and practice in Nigeria, pp. 41-45. In. Utilization of sorghum and millets (Gomez, M.I. et al (Eds)). International Crops Research Institute for the SemiArid Tropics, Patancheru, A.P. 502 324, India.

Koliatsou, M. \& Palmer, G.H. (2003). A new method to assess mealiness and steeliness of barley varieties and relationship of mealiness with malting parameters. Journal of the American Society of Brewing Chemists 61: 114-118. https://doi.org/10.1094/ASBCJ-61-0114

Kongkaew, A., Usansa, U. \& Wanapu, C. (2012). Optimization of wort production from rice malt using enzymes and barley malt. Afr. J. Biotechnol., 11: 9941-9949.

Kuiper, S., Rijn, C.V., Nijdam, W. \& Raspe, O. (2002). Filtration of lager beer with microsieves: Flux, permeate haze and in-line microscope observations. Journal of Membrane Science 196: 159-170. https://doi.org/10.1016/S0376-7388(01)00553-1

Kunze, W. (2004). Technology Brewing and Malting. Berlin, Germany: VLB Publishers. pp 968, ISBN: 978-3921690773

Leiper, K.A. \& Miedl, M. (2006). Brewhouse Technology. In: Handbook of brewing, Second Edition edited by Priest, F.G. and Stewart, G.G. Taylor and Francis Group, Florida, USA.

Lekkas, C. Stewart, G.G., Hill, A., Taidi, B. \& Hodgson, J. (2005). The importance of Free Amino Acid Nitrogen in wort and beer. Technical Quarterly Master Breweries Association of Americas 42(2): 113-116.

Leon, K., Mery, D., Pedreschi, F. \& Leon, J. (2006). Colour measurement in L* $a^{*} b^{*}$ units from RGB digital images. Food Research International 39(10): 1084-1091. https://doi.org/10.1016/j.foodres.2006.03.006 
1037 Lewis, M.J. \& Young, T.W. (2002). Brewing. Springer. Pp. 168-171.

1038 Mayer, H., Marconi, O., Regnicoli, G. F., Perretti, G., \& Fantozzi, P. (2014). Production

1039 of a saccharifying rice malt for brewing using different rice varieties and malting

1040

1041 parameters. Journal of Agricultural and Food Chemistry 62: 5366 - 5377.

1042 https://doi.org/10.1021/jf501462a

1043

1044

1045

Mayer, H., Marconi, O., Regnicoli, G.F., Perretti, G. \& Fantozzi, P. (2014). Production

1046

1047

1048

Montañez-Soto, J.L., González-Hernández, L.H., Venegas-González, J.,

1049

1050

1051

1052

1053

1054

Nicanor, A.B. \& González-Cruz, L. (2013). Effect of the Fructose and Glucose Concentration on the Rheological behaviour of High Fructose Syrups. African Journal of Biotechnology 12(12): 1401-1407.

Muoria, J.K. \& Bechtel, P.J. (1998). Diastatic power and $\alpha$-Amylase activity in Millet, Sorghum, and Barley grains and Malts. Journal of the American Society of

1055 Brewing Chemists 56(4): 131-135. https://doi.org/10.1094/ASBCJ-56-0131

1056

1057

Noonan, G.J. (2003). New Brewing Lager Beer. Brewers Publication, a division of the Brewers Association, Colorado, USA.

Nwanekezi, E.C., Osuji, C.M. \& Onyeneke, E.N. (2007). Brewing and Beverage Technology. $2^{\text {nd }}$ ed. Supreme publishers, 47 Okigwe Road Owerri, Imo State, Nigeria.

1061

O’Rourke (2002a). Malt Specifications and Brewing Performance. Brewer

1062 International 2(10): 27-30.

1063 O'Rourke, T. (2002b). The function of wort boiling. Brewer International 2(2): 17-

1064 19.

1065 Odibo, F.J.C., Nwankwo, L.N., \& Agu, R.C. (2002). Production of malt extract and beer from Nigerian sorghum varieties. Process Biochemistry 37 (8): 851-855.

1067 Ofoedu, C.E., Osuji, C.M., Omeire, G.C., Ojukwu, M., Okpala, C.O.R. \& 
1068

1069

1070

1071

1072

1073

1074

1075

1076

1077

1078

1079

1080

1081

1082

1083

1084

1085

1086

1087

1088

1089

1090

1091

1092

1093

1094

1095

1096

1097

Korzeniowska, M. (2020). Functional properties of syrup from malted and unmalted rice of different varieties: A comparative study. J. Food Sci. 85(10): 3081-3093. https://doi.org/10.1111/1750-3841.15446

Ofoedu, C.E., Osuji, C.M. \& Ojukwu, M. (2019). Sugar Profile of Syrups from Malted and Unmalted Rice of Different Varieties. Journal of Food Research 8(1):52-59. https://doi.org/10.5539/jfr.v8nlp52.

Ogbeide, S.O. (2011). Investigating the use of sorghum as malted barley adjunct in brewing process. Journal of Emerging Trends in Engineering and Applied Sciences 2(3): 521-524.

Ogbonna, A.C. (2002). Studies on malting parameters, purification and characterization of proteolytic enzymes from sorghum malt varieties. Published PhD thesis, University of Nigeria, Nsukka.

Okafor, N. \& Aniche, G.N. (1980). Brewing a Lager Beer from Nigeria sorghum. Brewing and Distilling International 10: 32-35.

Okafor, N. \& Iwouno, J. (1991): Malting and Brewing qualities of some Nigeria rice (Oriza sativa). World Journal of Microbiology and Biotechnology, 6:187-194. https://doi.org/10.1007/BF01200940

Okpiaifo, G., Durand-Morat, A., West, G.H., Nalley, L.L., Nayaga Jr., R.M., \& Wailes, E.J. (2020). Consumers' preferences for sustainable rice practices in Nigeria. Global Food Security 24: 100345. https://doi.org/10.1016/j.gfs.2019.100345

Olatunji, O., Jibogun, A.C., Anibaba, T.S., Oliyide, V.O., Ozumba, A.U., Oniwinde, A.B., \& Koleoso, O. (1993). Effect of different mashing procedures on the quality of sorghum beer. Journal of the American Society of Brewing Chemists 51(2): 6770. https//doi.org/10.1094/ASBCJ-51-0067

Oliver, G. \& Colicchio, T. (2012). The oxford companion to beer. Oxford University Press, USA.

Omar, K.A., Salih, B.M., Abdulla, N.Y., Hussin, B.H. \& Rassul, S.M. (2016). Evaluation of starch and sugar content of different rice samples and study of their physical properties. Indian Journal of Natural Sciences, 6(36): 11084-11088.

Organization for Economic Cooperation and Development/Food and Agriculture 
Organization (OECD/FAO) (2019). OECD-FAO Agricultural Outlook 2019-2028.

1100 Osuji, C.M.\& Anih, P.O. (2011). Physical and Chemical Properties of Glucose Syrup from Different Cassava Varieties. Nigerian Food Journal 29(1):83-89.

Osuji, C.M., Ofoedu, C.E. \& Ojukwu, M. (2019). Proximate, malting characteristics and grain quality properties of some Nigerian rice of different varieties. Research Journal of Chemical Sciences, 9(2): 1-10.

Osuji, C.M., Ofoedu, C.E., Omeire, G.C.\& Ojukwu, M. (2020). Colour analysis of syrup from malted and unmalted rice of different varieties. Croatian Journal of Food Science and Technology, 12(1): 1-9. https://doi.org/10.17508/CJFST.2020.12.1.03

Othman, R.S. \& Omar, K.A. (2017). Study of starch content and a variety of physical characteristics of rice (Oryza sativa L.). Polytechnic Journal, 12:16.

Palmer, G.H. (2006). Barley and Malt. In: Handbook of Brewing, Second Edition edited by Priest, F.G. and Stewart, G.G. Taylor and Francis Group, Florida, USA. P. 148.https://doi.org/10.1201/9781420015171.ch5

Palmer, J. (2009). Attenuation: Advanced Brewing. http://byo.com/malt/item/1895-attenuation-advanced-brewing. Accessed March 21, 2020.

Panthare, P.B., Opara, U.L. \& Al-Said, F.A. (2013). Colour measurement and analysis in fresh and processed foods. A Review. Food and Bioprocess Technology 6: 3660. https://doi.org/10.1007/s11947-012-0867-9

Papazian, C. (2006). Beer Styles: Their origins and classification. In: Handbook of Brewing, Second Edition edited by Priest, F.G. and Stewart, G.G. Taylor and Francis Group, Florida, USA. https://doi.org/10.1201/9781420015171.ch2

Pedley, J. (1996). Determination of dissolved solids (Brix) - A comparison of

Polan, V., Eisner, A. \& Vytras, K. (2015). Simple and rapid determination of ethanol content in beer using an Amperometric Biosensor. Chemosensors 3: 169-177.

1128 Pugh, T.A., Maurer, J.M. \& Pringle, A.T. (1997). The impact of wort nitrogen 
1129

1130

1131

1132

1133

1134

1135

1136

1137

1138

1139

1140

1141

1142

1143

1144

1145

1146

1147

1148

1149

1150

1151

1152

1153

1154

1155

1156

1157

1158

1159

limitation on yeast fermentation performance and diacetyl. Technical Quarterly Master Breweries Association of Americas 34: 185-189.

Roberto, I.C., Castro, R.C.A., Silva, J.P.A. \& Mussato, S.I. (2020). Ethanol production from high solid loading of rice straw by simultaneous saccharification and fermentation in a non-conventional reactor. Energies, 13(8): 1-17.

Russell, I. (2006). Yeast. In: Handbook of Brewing, Second Edition edited by Priest, F.G. and Stewart, G.G. Taylor and Francis Group, Florida, USA. https://doi.org/10.1201/9781420015171.ch8

Russon, M-A. (2019). Boosting rice production in Nigeria. BBC News. Published 12 April 2019. https://www.bbc.com/news/business-47858725/ Accessed 08 June 2020.

Sadosky, P.T. (2007). Effects of Malting and Mashing conditions on the Molecular weights of Arabinoxylan and Beta-Glucan in wort. A dissertation submitted to the Graduate Faculty of the North Dakota State University of Agriculture and Applied Science.

Sanchez-Moreno, C., Plaza, L., De Ancos, B. \& Cano, M.P. (2006). Nutritional characterization of commercial traditional pasteurized tomato juices: Carotenoids, vitamin C and radical scavenging capacity. Food Chemistry 98: 749-756. https://doi.org/10.1016/j.foodchem.2005.07.015

Shimizu, H., Mizuno, S., Hiroshima, T. \& Shioya, S. (2002). Effect of carbon and nitrogen additions on consumption activity of apparent extract of yeast cells in a brewing process. Journal of American Society of Brewing Chemists 60: 163-169. https://doi.org/10.1094/ASBCJ-60-0163

Shotripuk, A., Kittianong,P., Suphantharika, M \& Muangnaph, C.(2005). Application of rotary microfiltration in debittering process of spent brewer's yeast. Bioresource Technology, 17: 1851-1859. https://doi.org/10.1016/j.biortech.2005.01.035

Shumin, H., Jianjun, D., Wei, F., Junhong, Y., Hua, Y., Shuld, H., Jia, L., Shuxia, H. \& Xiaohua, Z. (2014). The influence of proteolytic and cytolytic enzymes on starch degradation during mashing. J. Inst. Brew. 120: 379-384.

Siebert, K.J., Carrasco, A. \& Lynn, P.Y. (1996). Formation of proteinpolyphenols haze in beverages. Journal of Agricultural and Food Chemistry 44: $1997-$ 2005. https://doi.org/10.1021/jf950716r

Peer) reviewing PDF | (2020:10:54302:1:1:NEW 16 Jan 2021) 
1160 Skendi, A. \& Papageorgiou, M. (2018). Influence of kilning temperature on chemical

1161

1162

1163

1164

1165

1166

1167

1168

1169

1170

1171

1172

1173

1174

1175

1176

1177

1178

1179

1180

1181

1182

1183

1184

1185

1186

1187

1188

1189

1190

composition of a Greek Barley malt and its wort properties. Millenium, 2(7): 49-58.

Sripriya, G., Anthony, U. \& Chandra, T.S. (1997). Changes in carbohydrate, free amino acids, organic acids, phytate and $\mathrm{HCl}$ extractability of minerals during germination and fermentation finger millet (Eleusine coracana). Food Chemistry 58 (4): 345-350. https://doi.org/10.1016/S0308-8146(96)00206-3

Steiner, E., Becker, T. \& Gastl, M. (2010). Turbidity and Haze Formation in Beer - Insights and Overview. Journal of the Institute of Brewing 116(4): 360-368. https://doi.org/10.1002/j.2050-0416.2010.tb00787.x

Stewart, G.G. (2004). The chemistry of beer instability. Journal of Chemical Education 81:963. https://doi.org/10.1021/ed081p963

Stewart, G.G., Hill, A. \& Lekkas, C. (2013). Wort FAN - Its characteristics and importance during fermentation. Journal of American Society of Brewing Chemists 71(4): 179-185.https://doi.org/10.1094/ASBCJ-2013-0921-01

Subramanian, N., Sambasiva R.N., Jambunathan, R., Murty, D.S. \& Reddy, B.V.S. (1995). The effect of malting on the extractability of proteins and its relationship to diastatic activity in sorghum. Journal of Cereal Science 21:283-289. https://doi.org/10.1006/jcrs.1995.0031

Taylor J. R. N., Dlamini, B. C. \& Kruger J. (2013).The science of the tropical cereals sorghum, maize and rice in relation to lager beer brewing Institute for Food, Nutrition and Well-being and Department of Food Science, University of Pretoria, South Africa.

Teeravivattanakit, T., Baramee, S., Phitsuwan, P., Sornyotha, S., Waeonukul, R. Pason, P., Tachaapiukoon, C., Poomputsa, K., Kosugi, A., Sakka, K. \& Ratanakhanokchai, K. (2017). Chemical pretreatment-independent saccharifications of xylan and cellulose of rice straw by bacterial weak lignin-binding xylanolytic and cellulolytic enzymes. Applied and Environmental Microbiology, 83(2): 1-15.

Usansa, U., Burberg, F., Geiger, E., Back, W., Wanapu, C., Arendt, E.K., Kreisz, S., Boonkerd, N., Teaumroong, N. \& Zarnkow, M. (2011). Optimization of malting conditions for two black rice varieties, black non-waxy rice and black waxy rice (Oryza sativa 1. Indica). J. Inst. Brew. 117, 39-46.

Peer) reviewing PDF | (2020:10:54302:1:1:NEW 16 Jan 2021) 
1191 USDA - ERS (2019). United States Department of Agriculture, Economic

1192 Research Service (USDA - ERS). International Baseline Data: 2019 International Long-

1193 Term Projections to 2028 (2019). https://www.ers.usda.gov/data-products/international-

1194 baseline-data/ Accessed 15 th April 2020.

1195 Wani, A.A., Singh, P., Shah, M.A., Schweiggert-Weisz, U., Gul, K. \& Wani, I.A.

1196 (2012). Rice Starch Diversity: Effects on structural, morphological, thermal, and

1197 physicochemical properties - A Review. Comprehensive Reviews in Food Science and

$1198 \quad$ Food Safety, 11: 417-436.

1199 Whistler, R. \& Bemiller, J. (2008). Carbohydrate Chemistry for Food Scientists.

$1200 \quad$ Food Australia, 60(4): 146.

1201 World Data Atlas (2020). Nigeria -Rice, paddy production quantity,

1202 https://knoema.com/atlas/Nigeria/topics/Agriculture/Crops-Production-Quantity-

1203 tonnes/Rice-paddy-production/ Accessed 08 June 2020.

1204 Zhao, R., Bean, S.R., Ioerger, B.P., Wang, D. \& Boyle, D.L. (2008). Impact of

1205 mashing on sorghum proteins and its relationship to ethanol fermentation. Journal of

1206 Agriculture Food Chemistry. 56: 946-953. https://doi.org/10.1021/jf072590r

1207 Zhu, F. (2017). Barley Starch: Composition, structure, properties, and modifications.

1208 Comprehensive Reviews in Food Science and Food Safety, 16: 558-579. 
Figure 1

Schematic overview of the experimental program. 


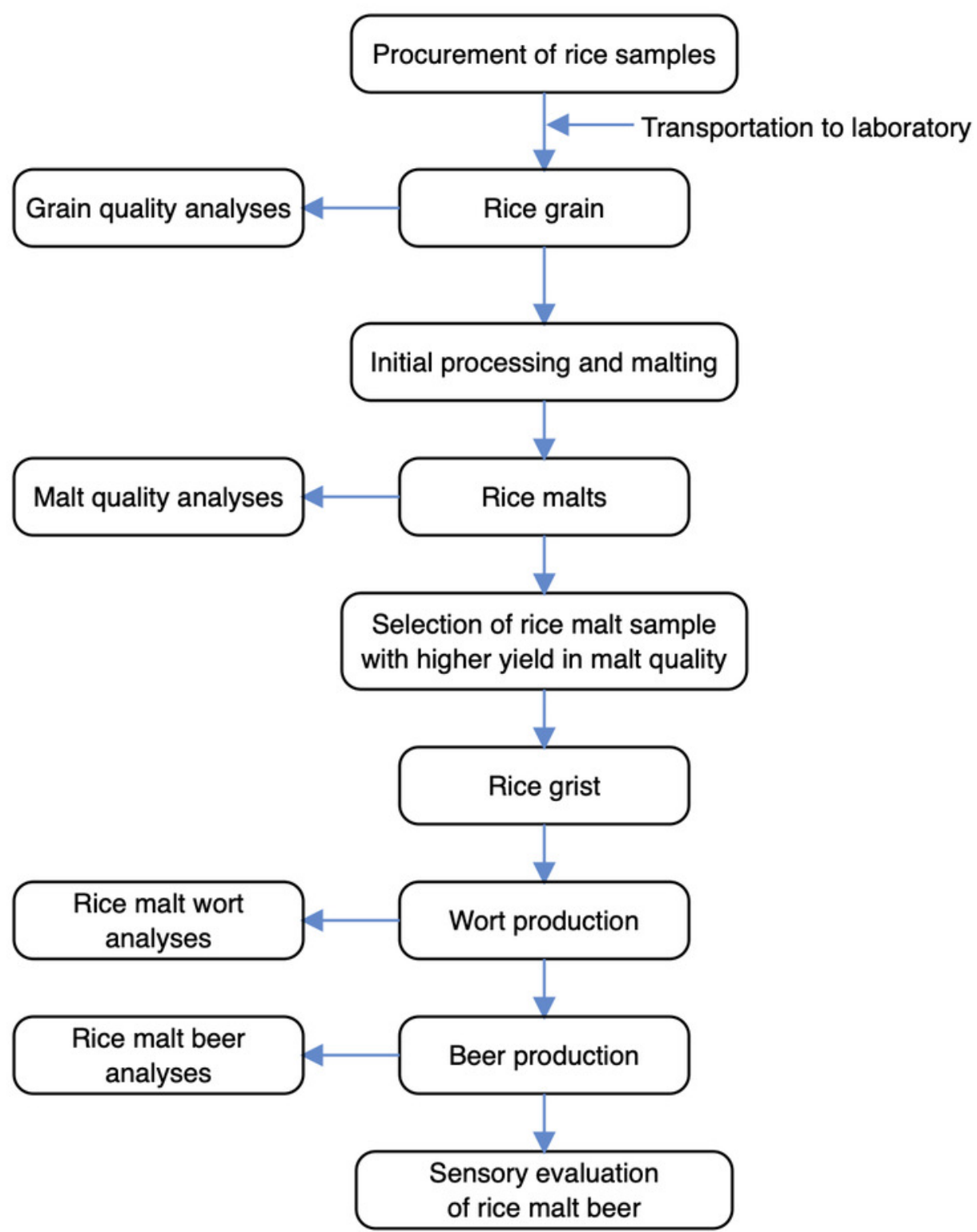


Figure 2

Flow diagram for the production of rice malt wort 


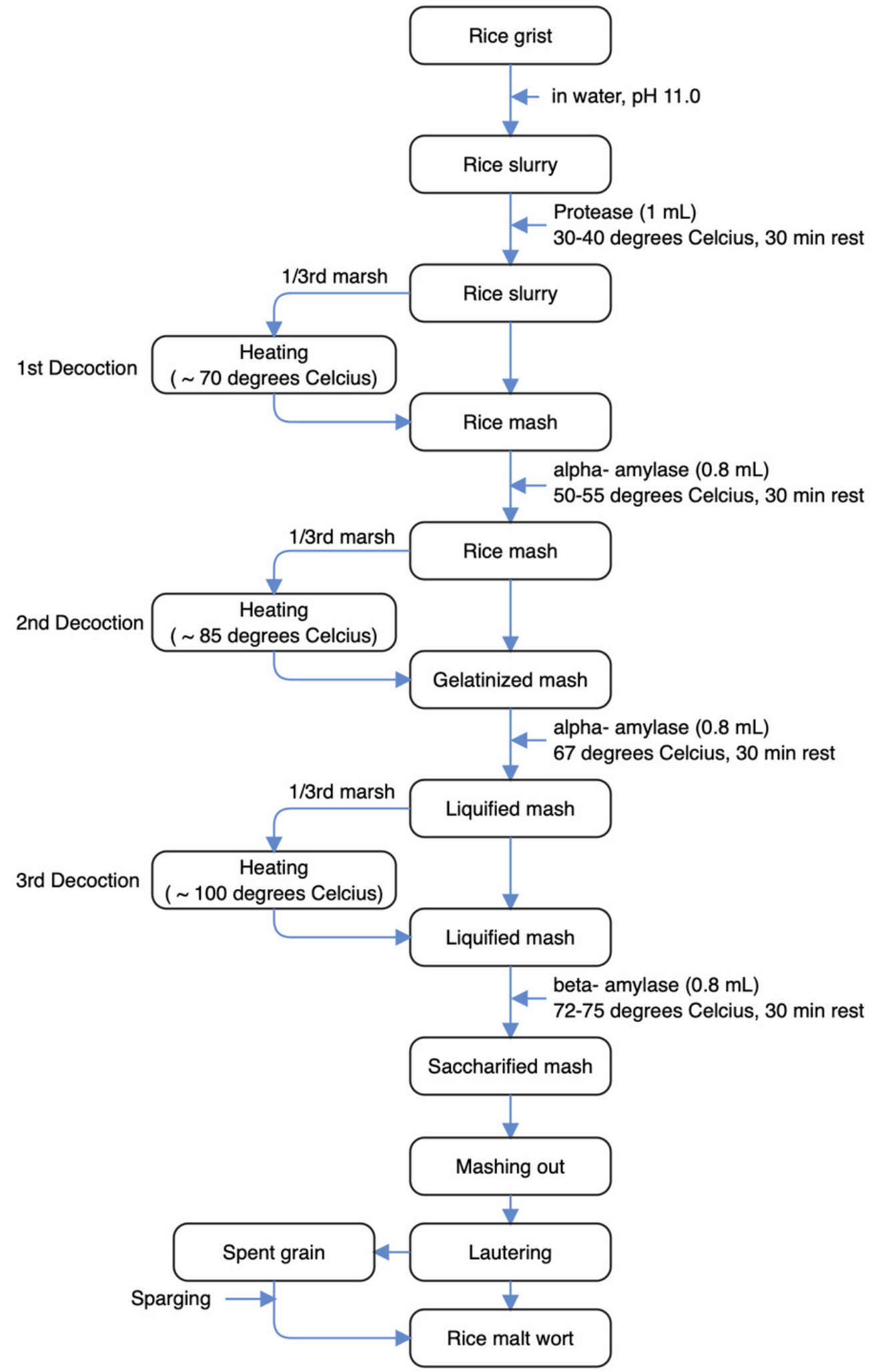




\section{Table 1 (on next page)}

Grain characteristics of rice varieties 
1 Table 1: Grain characteristics of rice varieties

\begin{tabular}{lllrr}
\hline \multicolumn{1}{c}{ SAMPLES } & \multicolumn{1}{c}{ TKW (g) } & GE (\%) & GC (\%) & DoS (\%) \\
\hline FARO 44 & $25.81^{\mathrm{c}} \pm 0.01$ & $86.50^{\mathrm{c}} \pm 0.06$ & $92.50^{\mathrm{b}} \pm 0.14$ & $55.00^{\mathrm{a}} \pm 0.16$ \\
FARO 57 & $26.11^{\mathrm{b}} \pm 0.16$ & $93.50^{\mathrm{b}} \pm 0.07$ & $93.00^{\mathrm{b}} \pm 0.00$ & $50.98^{\mathrm{b}} \pm 0.07$ \\
NERICA 7 & $27.01^{\mathrm{a}} \pm 0.07$ & $95.00^{\mathrm{a}} \pm 0.98$ & $95.50^{\mathrm{a}} \pm 0.10$ & $49.96^{\mathrm{c}} \pm 0.09$ \\
LSD & $\mathbf{0 . 2 4}$ & $\mathbf{1 . 5 0}$ & $\mathbf{1 . 5 0}$ & $\mathbf{0 . 4 4}$ \\
\hline \multicolumn{5}{r}{} \\
\end{tabular}

3 a,b....means with the same superscript along a column for each parameter is not significantly

4 different $(\mathrm{P}>0.05)$

$5 \mathrm{TKW}=$ Thousand kernel weight; GE = Germination energy; Germinative capacity; DoS =

6 Degree of steeping 
Table 2 (on next page)

The CWE $(\mathrm{g} / 100 \mathrm{~g})$ of rice malts subject to varying steeping durations, germination periods, and kilning temperatures 
1 Table 2: The CWE (g/100g) of rice malts subject to varying steeping durations,

2 germination periods, and kilning temperatures

\begin{tabular}{|c|c|c|c|c|c|}
\hline \multicolumn{3}{|c|}{ Malting conditions } & \multicolumn{3}{|c|}{ Rice varieties } \\
\hline \multirow{2}{*}{$\begin{array}{l}\text { Steeping } \\
\text { duration } \\
\text { (hours) }\end{array}$} & \multirow{2}{*}{$\begin{array}{l}\text { Germination } \\
\text { period (days) }\end{array}$} & \multirow{2}{*}{$\begin{array}{l}\text { Kilning } \\
\text { temperature } \\
\left({ }^{\circ} \mathrm{C}\right)\end{array}$} & & & \\
\hline & & & FARO 44 & FARO 57 & NERICA 7 \\
\hline \multirow{6}{*}{18} & \multirow[t]{2}{*}{2} & 50 & $21.66^{\mathrm{d}} \pm 0.03$ & $19.43^{c} \pm 0.28$ & $10.95^{1} \pm 0.01$ \\
\hline & & 55 & $22.28^{\mathrm{b}} \pm 0.06$ & $14.39^{\mathrm{j}} \pm 0.42$ & $12.68^{\mathrm{i}} \pm 0.04$ \\
\hline & \multirow[t]{2}{*}{3} & 50 & $21.84^{\mathrm{c}} \pm 0.10$ & $13.99^{\mathrm{k}} \pm 0.06$ & $11.73^{\mathrm{k}} \pm 0.06$ \\
\hline & & 55 & $22.88^{\mathrm{a}} \pm 0.13$ & $11.44^{\mathrm{m}} \pm 0.06$ & $13.31^{\mathrm{f}} \pm 0.07$ \\
\hline & \multirow[t]{2}{*}{4} & 50 & $20.45^{j} \pm 0.08$ & $16.51^{\mathrm{h}} \pm 0.07$ & $12.68^{\mathrm{i}} \pm 0.06$ \\
\hline & & 55 & $20.53^{\mathrm{hi}_{ \pm}} 0.17$ & $14.38^{\mathrm{j}} \pm 0.11$ & $20.25^{c} \pm 0.17$ \\
\hline \multirow{6}{*}{24} & \multirow[t]{2}{*}{2} & 50 & $20.77_{ \pm 0.14}^{f}$ & $20.58^{\mathrm{b}} \pm 0.14$ & $12.52^{\mathrm{j}} \pm 0.08$ \\
\hline & & 55 & $20.95^{\mathrm{e}} \pm 0.14$ & $15.17^{\mathrm{i}} \pm 0.10$ & $14.94^{\mathrm{d}} \pm 0.10$ \\
\hline & \multirow[t]{2}{*}{3} & 50 & $20.58^{\mathrm{gh}} \pm 0.11$ & $18.24^{\mathrm{e}} \pm 0.10$ & $12.52^{\mathrm{j}_{ \pm}} 0.07$ \\
\hline & & 55 & $20.76^{f} \pm 0.06$ & $13.20^{1} \pm 0.04$ & $23.16^{\mathrm{a}} \pm 0.07$ \\
\hline & \multirow[t]{2}{*}{4} & 50 & $19.81^{1} \pm 0.08$ & $16.911_{ \pm} \mathrm{g}_{0.07}$ & $12.93^{\mathrm{h}} \pm 0.57$ \\
\hline & & 55 & $20.49^{\mathrm{ij}} \pm 0.08$ & $17.18^{f_{ \pm}} \pm 0.07$ & $21.13^{\mathrm{b}} \pm 0.08$ \\
\hline \multirow{6}{*}{30} & \multirow[t]{2}{*}{2} & 50 & $18.50^{\mathrm{n}_{ \pm}} 0.04$ & $22.13^{\mathrm{a}} \pm 0.06$ & $13.32^{\mathrm{f}_{ \pm}}+0.03$ \\
\hline & & 55 & $19.72^{\mathrm{m}} \pm 0.13$ & $16.51^{\mathrm{h}} \pm 0.11$ & $17.19^{\mathrm{g}} \pm 0.11$ \\
\hline & \multirow[t]{2}{*}{3} & 50 & $19.61^{\mathrm{k}} \pm 0.14$ & $18.98^{\mathrm{d}} \pm 0.13$ & $13.50^{\mathrm{f}} \pm 0.10$ \\
\hline & & 55 & $20.58^{\mathrm{g}} \pm 0.03$ & $15.17^{\mathrm{i}} \pm 0.03$ & $14.54^{\mathrm{d}} \pm 0.01$ \\
\hline & \multirow[t]{2}{*}{4} & 50 & $18.49^{n} \pm 0.06$ & $19.03^{\mathrm{d}} \pm 0.06$ & $13.69^{f} \pm 0.04$ \\
\hline & & 55 & $20.46^{\mathrm{ij}_{ \pm}}{ }_{0.08}$ & $16.51^{\mathrm{h}} \pm 0.07$ & $16.34^{\mathrm{f}} \pm 0.07$ \\
\hline LSD & & & 0.27 & 0.59 & 0.45 \\
\hline
\end{tabular}

Values are the means of duplicate determinations $(N=2)$

a,b....means with the same superscript along a column for each rice variety is not significantly 


\section{Table 3 (on next page)}

The HWE $\left(L^{\circ} / \mathrm{kg}\right)$ of rice malts subject to varying steeping durations, germination periods, and kilning temperatures 
1 Table 3: The HWE $\left(\mathrm{L}^{\circ} / \mathrm{kg}\right)$ of rice malts subject to varying steeping durations, germination

2 periods, and kilning temperatures

\begin{tabular}{|c|c|c|c|c|c|}
\hline \multirow{4}{*}{$\begin{array}{l}\text { Steeping } \\
\text { duration } \\
\text { (h) }\end{array}$} & \multicolumn{2}{|c|}{ Malting conditions } & \multicolumn{3}{|c|}{ Rice varieties } \\
\hline & \multirow{3}{*}{$\begin{array}{l}\text { Germination } \\
\text { period (days) }\end{array}$} & \multirow{3}{*}{$\begin{array}{l}\text { Kilning } \\
\text { temperature } \\
\left({ }^{\circ} \mathrm{C}\right)\end{array}$} & & & \\
\hline & & & & & \\
\hline & & & FARO 44 & FARO 57 & NERICA 7 \\
\hline \multirow{6}{*}{18} & \multirow[t]{2}{*}{2} & 50 & $121.56^{\mathrm{b}} \pm 0.48$ & $103.05^{\mathrm{h}} \pm 0.41$ & $130.06^{\mathrm{h}} \pm 0.54$ \\
\hline & & 55 & $103.18^{\mathrm{e}} \pm 1.02$ & $103.18^{\mathrm{gh}} \pm 0.99$ & $182.10^{\mathrm{b}} \pm 1.80$ \\
\hline & \multirow[t]{2}{*}{3} & 50 & $103.18^{\mathrm{e}} \pm 0.74$ & $105.17^{f} \pm 0.75$ & $163.71^{\mathrm{e}} \pm 1.16$ \\
\hline & & 55 & $136.56^{\mathrm{a}} \pm 1.16$ & $100.15^{\mathrm{i}} \pm 0.88$ & $182.10^{\mathrm{b}} \pm 1.54$ \\
\hline & \multirow[t]{2}{*}{4} & 50 & $106.22^{\mathrm{d}} \pm 0.59$ & $160.43^{\mathrm{c}} \pm 0.91$ & $121.41^{\mathrm{k}} \pm 0.69$ \\
\hline & & 55 & $115.56^{\mathrm{c}} \pm 0.81$ & $105.17^{\mathrm{f}} \pm 0.74$ & $163.90^{\mathrm{e}} \pm 1.13$ \\
\hline \multirow{6}{*}{24} & \multirow[t]{2}{*}{2} & 50 & $100.15^{f} \pm 1.13$ & $106.22^{\mathrm{e}} \pm 1.20$ & $166.91^{\mathrm{d}} \pm 1.90$ \\
\hline & & 55 & $84.97^{\mathrm{j}} \pm 0.83$ & $106.22^{\mathrm{e}} \pm 1.02$ & $148.00^{\mathrm{f}} \pm 1.47$ \\
\hline & \multirow[t]{2}{*}{3} & 50 & $100.15^{f} \pm 0.17$ & $106.22^{\mathrm{e}} \pm 0.18$ & $182.10^{\mathrm{b}} \pm 0.31$ \\
\hline & & 55 & $91.04^{\mathrm{i}} \pm 0.44$ & $103.18^{\mathrm{gh}} \pm 0.51$ & $206.48^{\mathrm{a}} \pm 0.99$ \\
\hline & \multirow[t]{2}{*}{4} & 50 & $84.97^{\mathrm{j}} \pm 0.54$ & $106.22^{\mathrm{e}} \pm 0.68$ & $182.10^{\mathrm{b}} \pm 1.16$ \\
\hline & & 55 & $106.18^{\mathrm{d}} \pm 0.28$ & $103.48^{g} \pm 0.28$ & $133.70^{i} \pm 0.35$ \\
\hline \multirow{6}{*}{30} & \multirow[t]{2}{*}{2} & 50 & $51.06^{\mathrm{m}} \pm 0.33$ & $170.18^{\mathrm{a}} \pm 1.10$ & $139.60^{\mathrm{g}} \pm 0.91$ \\
\hline & & 55 & $75.98^{\mathrm{k}} \pm 0.24$ & $136.56^{\mathrm{d}} \pm 0.34$ & $127.50^{\mathrm{j}} \pm 0.41$ \\
\hline & \multirow[t]{2}{*}{3} & 50 & $75.98^{\mathrm{k}} \pm 0.65$ & $166.91^{\mathrm{b} \pm 1.41}$ & $127.50^{\mathrm{j}_{ \pm}} 1.08$ \\
\hline & & 55 & $97.06^{\mathrm{g}} \pm 0.55$ & $106.22^{\mathrm{e}} \pm 0.78$ & $163.90^{\mathrm{e}} \pm 0.93$ \\
\hline & \multirow[t]{2}{*}{4} & 50 & $60.70^{1} \pm 0.21$ & $106.02^{\mathrm{e}} \pm 0.35$ & $172.98^{c} \pm 0.59$ \\
\hline & & 55 & $94.21^{\mathrm{h}} \pm 0.62$ & $103.08^{\mathrm{h}} \pm 0.68$ & $133.70^{i} \pm 0.89$ \\
\hline LSD & & & 0.49 & 0.30 & 1.19 \\
\hline
\end{tabular}

Values are the means of duplicate determinations $(N=2)$

a,b....means with the same superscript along a column for each rice variety is not significantly 


\section{Table 4 (on next page)}

The DP ( ${ }^{\circ}$ Lintner) of rice malts subject to varying steeping durations, germination periods, and kilning temperatures 
1 Table 4: The DP ( ${ }^{\circ}$ Lintner) of rice malts subject to varying steeping durations, germination

2 periods, and kilning temperatures

\begin{tabular}{|c|c|c|c|c|c|}
\hline \multicolumn{3}{|c|}{ Malting conditions } & \multicolumn{3}{|c|}{ Rice varieties } \\
\hline \multirow{2}{*}{$\begin{array}{l}\text { Steeping } \\
\text { duration } \\
\text { (h) }\end{array}$} & \multirow{2}{*}{$\begin{array}{l}\text { Germination } \\
\text { period (days) }\end{array}$} & \multirow{2}{*}{$\begin{array}{l}\text { Kilning } \\
\text { temperature } \\
\left({ }^{\circ} \mathrm{C}\right)\end{array}$} & & & \\
\hline & & & FARO 44 & FARO 57 & NERICA 7 \\
\hline \multirow{6}{*}{18} & \multirow[t]{2}{*}{2} & 50 & $78.00^{\mathrm{e}} \pm 0.74$ & $63.00^{f} \pm 0.59$ & $71.00^{j_{ \pm}}+0.66$ \\
\hline & & 55 & $92.00^{c} \pm 0.59$ & $22.00^{\mathrm{n}} \pm 0.14$ & $97.00^{\mathrm{g}_{ \pm}} 0.61$ \\
\hline & \multirow[t]{2}{*}{3} & 50 & $63.00^{\mathrm{g}} \pm 0.28$ & $50.00^{i} \pm 0.23$ & $48.00^{\mathrm{m}} \pm 0.21$ \\
\hline & & 55 & $150.00^{\mathrm{a}} \pm 0.23$ & $38.00^{1} \pm 0.06$ & $60.00^{1} \pm 0.10$ \\
\hline & \multirow[t]{2}{*}{4} & 50 & $80.00^{\mathrm{d}} \pm 0.37$ & $37.00^{1} \pm 0.17$ & $67.00^{\mathrm{k}} \pm 0.30$ \\
\hline & & 55 & $98.00^{\mathrm{b}} \pm 0.42$ & $26.00^{\mathrm{m}} \pm 0.11$ & $100.00^{\mathrm{e}} \pm 0.44$ \\
\hline \multirow{6}{*}{24} & \multirow[t]{2}{*}{2} & 50 & $43.00^{1} \pm 0.06$ & $80.00^{\mathrm{e}} \pm 0.11$ & $98.00^{\mathrm{f}} \pm 0.14$ \\
\hline & & 55 & $63.00^{\mathrm{f}} \pm 0.18$ & $39.00^{\mathrm{k}} \pm 0.11$ & $120.00^{c} \pm 0.34$ \\
\hline & \multirow[t]{2}{*}{3} & 50 & $50.00^{\mathrm{j}_{ \pm}} .21$ & $64.00^{f} \pm 0.27$ & $60.00^{1} \pm 0.25$ \\
\hline & & 55 & $52.00^{i} \pm 0.28$ & $52.00^{h} \pm 0.28$ & $143.00^{\mathrm{a}} \pm 0.79$ \\
\hline & \multirow[t]{2}{*}{4} & 50 & $44.00^{\mathrm{k}} \pm 0.34$ & $57.00^{\mathrm{g}} \pm 0.44$ & $60.00^{1} \pm 0.45$ \\
\hline & & 55 & $57.00^{\mathrm{h}} \pm 0.61$ & $39.01^{\mathrm{k}} \pm 0.41$ & $101.00^{\mathrm{e}} \pm 1.08$ \\
\hline \multirow{6}{*}{30} & \multirow[t]{2}{*}{2} & 50 & $38.00^{\mathrm{p}} \pm 0.15$ & $148.00^{\mathrm{a}} \pm 0.58$ & $102.00^{\mathrm{e}_{ \pm}} \pm 0.41$ \\
\hline & & 55 & $39.00^{\circ} \pm 0.38$ & $43.00^{j_{ \pm}} 0.42$ & $113.00^{\mathrm{d}} \pm 1.12$ \\
\hline & \multirow[t]{2}{*}{3} & 50 & $35.00^{\mathrm{q}} \pm 0.25$ & $135.00^{\mathrm{b}} \pm 0.96$ & $92.00^{\mathrm{h}} \pm 0.65$ \\
\hline & & 55 & $38.00^{p_{ \pm}} 0.32$ & $98.08^{\mathrm{c}} \pm 0.83$ & $138.00^{\mathrm{b}} \pm 1.17$ \\
\hline & \multirow[t]{2}{*}{4} & 50 & $39.00^{\circ} \pm 0.23$ & $92.00^{\mathrm{d}} \pm 0.52$ & $46.00^{\mathrm{m}} \pm 0.25$ \\
\hline & & 55 & $40.00^{\mathrm{m}} \pm 0.24$ & $43.00^{j_{ \pm}} .0 .25$ & $75.00^{i} \pm 0.45$ \\
\hline LSD & & & 0.73 & 0.98 & 1.63 \\
\hline
\end{tabular}

Values are the means of duplicate determinations $(N=2)$

a,b....means with the same superscript along a column for each rice variety is not significantly different $(\mathrm{P}>0.05)$ 


\section{Table 5 (on next page)}

Malt yield (MY), malting loss (ML), moisture content (MC), and total nitrogen (TN) of rice malt samples 
1 Table 5: Malt yield (MY), malting loss (ML), moisture content (MC), and total nitrogen

2 (TN) of rice malt samples

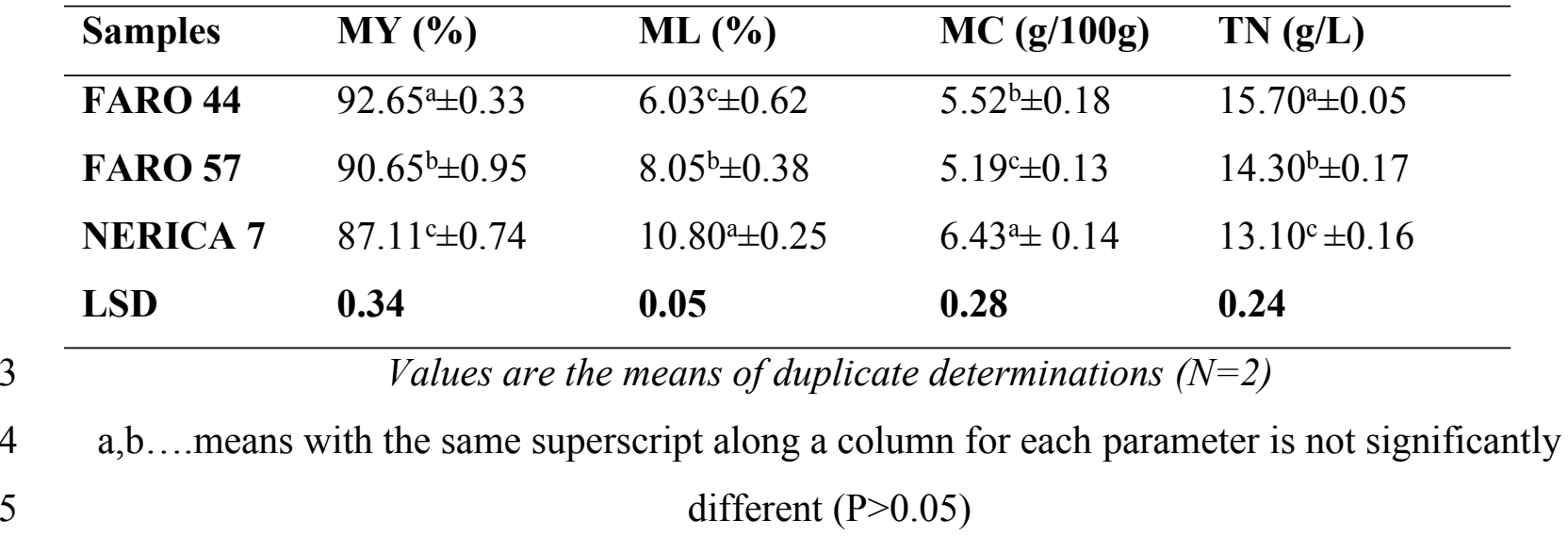


Table 6(on next page)

Sugar profile of rice malt wort samples 
1 Table 6: Sugar profile of rice malt wort samples

\begin{tabular}{lcccccc}
\hline SAMPLES & Maltotriose (\%) & Glucose (\%) & Maltose (\%) & Maltotetraose (\%) & Sucrose (\%) & Raffinose (\%) \\
\hline FARO 44 & $12.26^{\mathrm{c}} \pm 0.28$ & $11.23^{\mathrm{a}} \pm 0.16$ & $14.63^{\mathrm{b}} \pm 0.11$ & $0.63^{\mathrm{a}} \pm 0.04$ & $2.44^{\mathrm{b}} \pm 0.10$ & $0.07^{\mathrm{a}} \pm 0.00$ \\
FARO57 & $13.25^{\mathrm{b}} \pm 0.14$ & $11.63^{\mathrm{a}} \pm 0.71$ & $15.34^{\mathrm{a}} \pm 0.08$ & $0.53^{\mathrm{b}} \pm 0.03$ & $2.32^{\mathrm{c}} \pm 0.03$ & $0.05^{\mathrm{b}} \pm 0.00$ \\
NERICA 7 & $16.40^{\mathrm{a}} \pm 0.07$ & $10.84^{\mathrm{b}} \pm 0.06$ & $15.03^{\mathrm{a}} \pm 0.04$ & $0.44^{\mathrm{c}} \pm 0.06$ & $2.83^{\mathrm{a}} \pm 0.08$ & $0.06^{\mathrm{ab}} \pm 0.00$ \\
LSD & $\mathbf{0 . 0 3}$ & $\mathbf{0 . 0 2}$ & $\mathbf{0 . 0 3}$ & $\mathbf{0 . 0 3}$ & $\mathbf{0 . 0 3}$ & $\mathbf{0 . 0 1}$ \\
\hline
\end{tabular}

3 a,b....means with the same superscript along a column for each parameter is not significantly different $(\mathrm{P}>0.05)$ 


\section{Table 7 (on next page)}

The $\mathrm{pH}, \mathrm{TSN}(\mathrm{g} / \mathrm{L})$, Brix $(\mathrm{g} / 100 \mathrm{~g}), \mathrm{KI}(\%), \mathrm{FAN}(\mathrm{mg} / \mathrm{L}), \mathrm{DE}(\mathrm{g} / 100 \mathrm{~g})$ and OE $(\mathrm{g} / 100 \mathrm{~g})$ components of rice malt wort samples 
Table 7: The pH, TSN (g/L), Brix (g/100g), KI (\%), FAN (mg/L), DE (g/100g) and OE (g/100g) components of rice malt wort samples

\begin{tabular}{llllllll}
\hline Samples & $\mathbf{p H}$ & TSN $(\mathbf{g} / \mathbf{L})$ & $\begin{array}{l}\text { Brix } \\
(\mathbf{g} / \mathbf{1 0 0 g})\end{array}$ & $\mathbf{K I}(\mathbf{\%})$ & FAN $(\mathbf{m g} / \mathbf{L})$ & $\mathbf{D E}(\mathbf{g} / \mathbf{1 0 0 g})$ & $\mathbf{O E}(\mathbf{g} / \mathbf{1 0 0 g})$ \\
\hline FARO 44 & $5.40^{\mathrm{a}} \pm 0.38$ & $5.40^{\mathrm{a}} \pm 0.00$ & $14.65^{\mathrm{b}} \pm 0.07$ & $34.39^{\mathrm{c}} \pm 0.13$ & $108.56^{\mathrm{c}} \pm 0.08$ & $39.00^{\mathrm{a}} \pm 1.42$ & $11.15^{\mathrm{a}} \pm 0.05$ \\
FARO 57 & $5.30^{\mathrm{a}} \pm 0.17$ & $5.60^{\mathrm{a}} \pm 0.00$ & $16.36^{\mathrm{a}} \pm 0.42$ & $39.16^{\mathrm{b}} \pm 0.09$ & $112.23^{\mathrm{b}} \pm 0.28$ & $40.00^{\mathrm{a}} \pm 0.82$ & $12.66^{\mathrm{a}} \pm 0.04$ \\
NERICA 7 & $5.30^{\mathrm{a}} \pm 0.10$ & $5.80^{\mathrm{a}} \pm 0.00$ & $13.88^{\mathrm{c}} \pm 0.11$ & $44.27^{\mathrm{a}} \pm 0.28$ & $117.34^{\mathrm{a}} \pm 0.06$ & $37.00^{\mathrm{a}} \pm 0.01$ & $9.68^{\mathrm{a}} \pm 0.07$ \\
LSD & $\mathbf{N S}$ & $\mathbf{N S}$ & $\mathbf{0 . 5 8}$ & $\mathbf{3 . 2 0}$ & $\mathbf{4 . 3 2}$ & $\mathbf{N S}$ & $\mathbf{N S}$ \\
\hline \multicolumn{7}{c}{ Values are the means of duplicate determinations $(N=2)$} \\
\end{tabular}

a,b....means with the same superscript along a column for each parameter is not significantly different $(\mathrm{P}>0.05)$

$\mathrm{TSN}=$ Total soluble nitrogen; $\mathrm{KI}=$ Kolbach index; FAN = Free amino nitrogen;

$\mathrm{DE}=$ Dextrose equivalent; and $\mathrm{OE}=$ Original extract 


\section{Table 8(on next page)}

The $\mathrm{pH}$, colour $\left({ }^{\circ} \mathrm{EBC}\right), \mathrm{AE}(\mathrm{g} / \mathrm{100 \textrm {g }})$, alcohol content (\%ABV) and turbidity (NTU) of rice malt beer samples 
1 Table 8: The $\mathrm{pH}$, colour $\left({ }^{\circ} \mathrm{EBC}\right), \mathrm{AE}(\mathrm{g} / \mathbf{1 0 0 g})$, alcohol content (\%ABV) and turbidity

2 (NTU) of rice malt beer samples

\begin{tabular}{llllll}
\hline Samples & $\mathbf{p H}$ & $\begin{array}{l}\text { Colour } \\
\left({ }^{\circ} \mathbf{E B C}\right)\end{array}$ & $\begin{array}{l}\text { AE } \\
(\mathbf{g} / \mathbf{1 0 0 g})\end{array}$ & $\begin{array}{l}\text { Alcohol } \\
\text { content } \\
(\% \text { ABV) }\end{array}$ & $\begin{array}{l}\text { Turbidity } \\
\text { (NTU) }\end{array}$ \\
\hline FARO 44 & $3.80^{\mathrm{a}} \pm 0.44$ & $3.70^{\mathrm{a}} \pm 0.16$ & $4.59^{\mathrm{a}} \pm 0.74$ & $3.54^{\mathrm{b}} \pm 0.06$ & $5.30^{\mathrm{a}} \pm 0.01$ \\
FARO 57 & $3.90^{\mathrm{a}} \pm 0.59$ & $3.73^{\mathrm{a}} \pm 0.71$ & $4.57^{\mathrm{a}} \pm 1.07$ & $4.13^{\mathrm{a}} \pm 0.18$ & $4.80^{\mathrm{a}} \pm 0.17$ \\
NERICA 7 & $3.80^{\mathrm{a}} \pm 0.10$ & $3.20^{\mathrm{a}} \pm 0.42$ & $4.93^{\mathrm{a}} \pm 0.54$ & $2.82^{\mathrm{c}} \pm 0.50$ & $4.30^{\mathrm{a}} \pm 0.21$ \\
LSD & $\mathbf{N S}$ & $\mathbf{N S}$ & $\mathbf{N S}$ & $\mathbf{0 . 3 9}$ & $\mathbf{N S}$ \\
\hline
\end{tabular}

3 Values are the means of duplicate determinations $(N=2)$

a,b....means with the same superscript along a column for each parameter is not significantly 5 different $(\mathrm{P}>0.05)$

$6 \mathrm{AE}=$ Apparent extract; $\mathrm{ABV}=$ Alcohol by volume 
Table 9 (on next page)

The sensory attributes (colour, aroma, taste, mouthfeel, appearance, and overall acceptability) of rice malt beer samples 
1 Table 9: The sensory attributes (colour, aroma, taste, mouthfeel, appearance, and overall acceptability) of rice malt beer samples

\begin{tabular}{|c|c|c|c|c|c|c|}
\hline SAMPLES & Colour & Taste & Aroma & Mouthfeel & Appearance & Overall acceptability \\
\hline $\begin{array}{l}\text { Commercial } \\
\text { lager beer }\end{array}$ & $8.71^{\mathrm{a}} \pm 0.55$ & $8.19^{\mathrm{a}} \pm 0.13$ & $7.99^{\mathrm{a}} \pm 0.51$ & $8.51^{\mathrm{a}} \pm 0.25$ & $8.61^{\mathrm{a}} \pm 0.45$ & $8.40^{\mathrm{a}} \pm 0.38$ \\
\hline FARO 44 & $6.91^{b} \pm 0.33$ & $7.87^{b} \pm 0.32$ & $7.81^{\mathrm{a}} \pm 0.33$ & $6.96^{\mathrm{b}} \pm 0.32$ & $6.52^{b} \pm 0.32$ & $7.21^{\mathrm{b}} \pm 0.30$ \\
\hline FARO 57 & $6.66^{b} \pm 0.13$ & $7.69^{b} \pm 0.21$ & $7.54^{\mathrm{a}} \pm 0.16$ & $6.57^{b} \pm 0.41$ & $6.24^{b} \pm 0.23$ & $6.94^{b} \pm 0.08$ \\
\hline NERICA 7 & $6.87^{b} \pm 0.25$ & $7.82^{b} \pm 0.10$ & $7.80^{\mathrm{a}} \pm 0.51$ & $6.76^{\mathrm{b}} \pm 0.22$ & $6.41^{b} \pm 0.23$ & $7.13^{\mathrm{b}} \pm 0.24$ \\
\hline LSD & 0.85 & NS & NS & 1.22 & 0.93 & 0.56 \\
\hline
\end{tabular}

Values are the means of duplicate determinations $(N=2)$ 